\title{
Compartmentalized Proteomic Profiling Outlines the Crucial Role of the Classical Secretory Pathway during Recombinant Protein Production in Chinese Hamster Ovary Cells
}

Pérez-Rodriguez, Saumel; Wulff, Tune; Voldborg, Bjørn G; Altamirano, Claudia; Trujillo-Roldán, Mauricio A; Valdez-Cruz, Norma A

\section{Published in:}

ACS Omega

Link to article, DOI:

10.1021/acsomega.0c06030

Publication date:

2021

Document Version

Publisher's PDF, also known as Version of record

Link back to DTU Orbit

Citation (APA):

Pérez-Rodriguez, S., Wulff, T., Voldborg, B. G., Altamirano, C., Trujillo-Roldán, M. A., \& Valdez-Cruz, N. A. (2021). Compartmentalized Proteomic Profiling Outlines the Crucial Role of the Classical Secretory Pathway during Recombinant Protein Production in Chinese Hamster Ovary Cells. ACS Omega, 6(19), 12439-12458. https://doi.org/10.1021/acsomega.0c06030

\section{General rights}

Copyright and moral rights for the publications made accessible in the public portal are retained by the authors and/or other copyright owners and it is a condition of accessing publications that users recognise and abide by the legal requirements associated with these rights.

- Users may download and print one copy of any publication from the public portal for the purpose of private study or research.

- You may not further distribute the material or use it for any profit-making activity or commercial gain

- You may freely distribute the URL identifying the publication in the public portal 


\title{
Compartmentalized Proteomic Profiling Outlines the Crucial Role of the Classical Secretory Pathway during Recombinant Protein Production in Chinese Hamster Ovary Cells
}

\author{
Saumel Pérez-Rodriguez, Tune Wulff, Bjørn G. Voldborg, Claudia Altamirano, \\ Mauricio A. Trujillo-Roldán, and Norma A. Valdez-Cruz*
}

Cite This: ACS Omega 2021, 6, 12439-12458

Read Online

ABSTRACT: Different cellular processes that contribute to protein production in Chinese hamster ovary $(\mathrm{CHO})$ cells have been previously investigated by proteomics. However, although the classical secretory pathway (CSP) has been well documented as a bottleneck during recombinant protein (RP) production, it has not been well represented in previous proteomic studies. Hence, the significance of this pathway for production of RP was assessed by identifying its own proteins that were associated to changes in RP production, through subcellular fractionation coupled to shot-gun proteomics. Two $\mathrm{CHO}$ cell lines producing a monoclonal antibody with different specific productivities were used as cellular models, from which 4952 protein groups were identified, which represent a
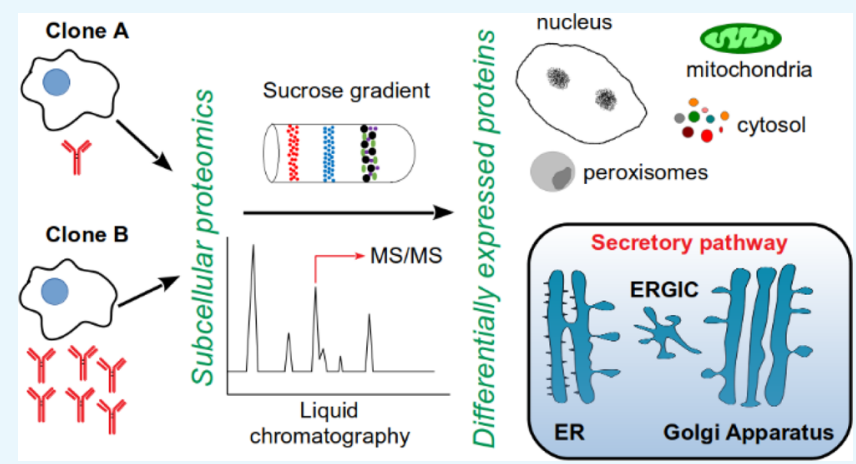
coverage of $59 \%$ of the Chinese hamster proteome. Data are available via ProteomeXchange with identifier PXD021014. By using SAM and ROTS algorithms, 493 proteins were classified as differentially expressed, of which about $80 \%$ was proposed as novel targets and one-third were assigned to the CSP. Endoplasmic reticulum (ER) stress, unfolded protein response, calcium homeostasis, vesicle traffic, glycosylation, autophagy, proteasomal activity, protein synthesis and translocation into ER lumen, and secretion of extracellular matrix components were some of the affected processes that occurred in the secretory pathway. Processes from other cellular compartments, such as DNA replication, transcription, cytoskeleton organization, signaling, and metabolism, were also modified. This study gives new insights into the molecular traits of higher producer cells and provides novel targets for development of new sub-lines with improved phenotypes for $\mathrm{RP}$ production.

\section{INTRODUCTION}

Chinese hamster ovary ( $\mathrm{CHO}$ ) cells have been widely employed for expression of recombinant proteins (RP), both in research and biopharmaceutical industries. This expression system has been used for production of $84 \%$ of approved antibodies in 2015-2018 period, which represent over half of all approvals during this time. ${ }^{1}$ The success of this cell line relies on several advantages such as a safety viral profile, ${ }^{2}$ human compatible glycosylation, ${ }^{3}$ and availability of specific culture media and supplements, ${ }^{4,5}$ sub-lines with different capabilities, ${ }^{6}$ and improved expression vectors and selection strategies. ${ }^{7}$ Therefore, given the importance of $\mathrm{CHO}$ cells, a deeper knowledge of their biology through genomic, transcriptomic, proteomic, and metabolomic studies has been gained in the last few years. ${ }^{8-11}$ Transcriptomic and proteomic profiles acquired under low temperature, ${ }^{12}$ butyrate addition, ${ }^{13}$ hyperosmotic pressure, ${ }^{14}$ cell engineering efforts, ${ }^{15}$ and contrasting phenotypes of protein degradation, ${ }^{16}$ production stability, ${ }^{19}$ and RP productivity, ${ }^{18-24}$ have led to the identification of targets related to improving productivity.
Seven whole cell proteomic studies of phenotypes with different specific productivity $\left(q_{\mathrm{p}}\right)$ of fusion proteins, ${ }^{18,21}$ monoclonal antibodies $(\mathrm{mAb}){ }^{19,20,22,23}$ and antibody fragments ${ }^{24}$ have been previously reported.

A myriad of cellular processes such as chromatin organization, cell cycle, metabolism of nucleic acids, proteins, fatty acids and carbon, cytoskeleton organization, response against reactive oxygen species (ROS), and vesicle-mediated transport have been linked to productivity in these studies. $^{18-24}$ However, because this information has been obtained from whole cell extractions, highlighted categories represent abundant proteins and have limited coverage of

Received: December 10, 2020

Accepted: February 24, 2021

Published: May 3, 2021

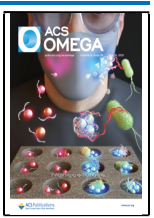




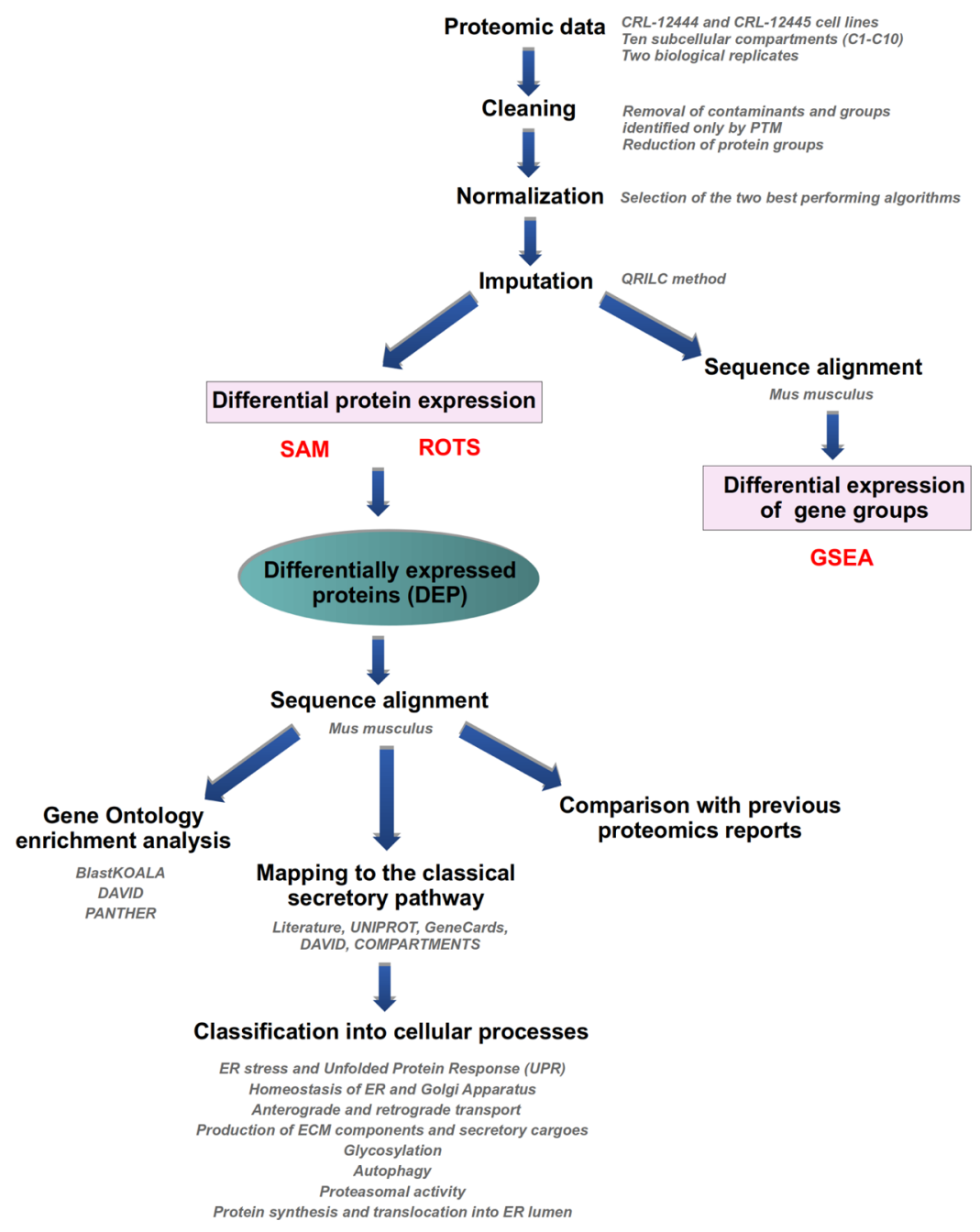

Figure 1. Data processing and identification of DEPs. Cleaning, normalization, and imputation were applied to proteomic data prior to the identification of targets with a statistical differential expression between CRL-12444 and CRL-12445 cells. Gene sets and proteins were identified, mapped to M. musculus proteome, classified according to GO terms, and compared with previous reports. Proteins from the secretory pathway were further assigned to several biological processes. ECM: extracellular matrix; ER: endoplasmic reticulum; and PTM: post-translational modifications.

proteome from some organelles such as those from the classical secretory pathway (CSP). Due to the central role of this pathway in metabolism of proteins and lipids, organelle biogenesis, cell cycle, apoptosis and proliferation, and to be recognized as a bottleneck for protein secretion in mammalian cells, $^{25-27}$ its characterization through subcellular proteomics represents a promising strategy for the identification of key targets associated to protein expression.

One established experimental approach to study individual organelles and especially the secretory pathway is the subcellular fractionation. This technique coupled to proteomics has been named subcellular proteomics, ${ }^{28,29}$ and its use over classical proteomics has shown a $30 \%$ increase in proteome coverage of pancreatic duct cells. ${ }^{30}$ Other advantages of this approach include protein tracking, quantification of low abundance of proteins, unraveling of organelle dynamics, and comprehension of the function and regulation of little-known proteins. $^{31-33}$ Actually, subcellular proteomics has been extensively used to study the protein composition of organelles $^{34,35}$ and protein dynamics ${ }^{36}$ and to explore new proteins involved in the secretory pathway. ${ }^{37,38}$ This approach has also been applied to characterize the subcellular distribution of proteins in breast cancer cells by combining isopycnic centrifugation, gel electrophoresis, and label-free MS/MS, leading to the assignment of several cancer-related proteins to multiple subcellular locations and to the identification of targets related to various cellular processes with critical roles in breast cancer development. ${ }^{39}$

Thus, in order to identify novel proteins from the secretory pathway of $\mathrm{CHO}$ cells linked to changes in $\mathrm{RP}$ production, we applied subcellular proteomics to two $\mathrm{CHO}$ cell lines producing a mAb against human interleukin 8 (IL-8) at different $q_{\mathrm{p}}$.

Here, we took advantage of a strategy that has been effective to enrich the proteomic fractions of subcellular organelles (Figure 1), which allowed the identification of 493 differentially expressed proteins (DEPs) with statistical significance between the higher (CRL-12445) and lower producer (CRL12444) CHO cells. These DEPs, and especially those from the CSP, will expand the engineering strategies to increase the titer and probably quality of RP. This proteomic analysis is a powerful approach to identify potential biotechnological targets that help to understand and improve RP bioprocesses. 
A

- Cell concentration CRL-12444 $\rightarrow$ Viability CRL-12444
- Cell concentration CRL-12445 + Viability CRL-12445
B

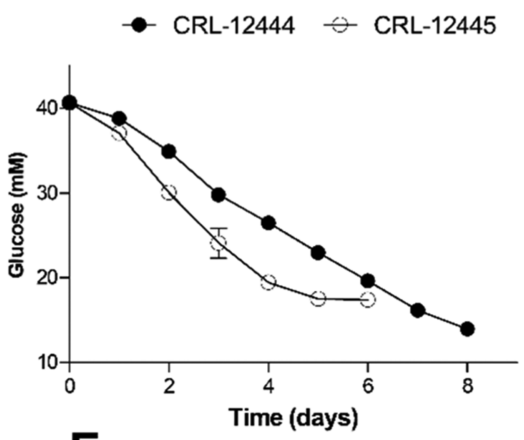

D

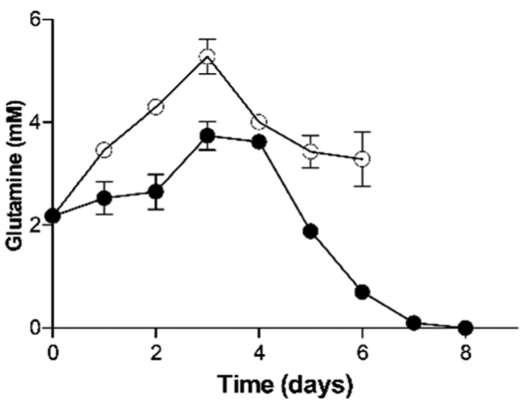

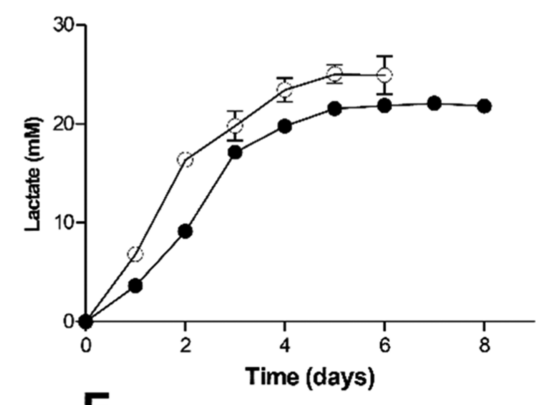

F

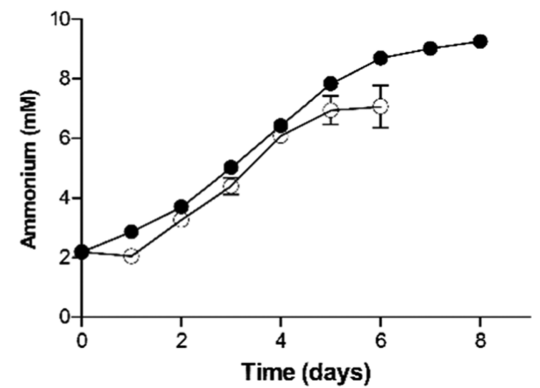

Figure 2. Growth kinetics and metabolite profiles. (A) Viable cell concentration (circles) and viability (squares) of CRL-12444 (filled) and CRL12445 (empty) cells were determined over time by the trypan blue dye exclusion method in a Neubauer chamber. Cells were collected for proteomic analysis at time indicated by the arrow. Concentration of glucose (B), lactate (C), glutamine (D), glutamate (E), and ammonium (F) were measured for CRL-12444 (filled circles) and CRL-12445 (open circles) cells. Standard deviation was calculated from three biological replicates.

\section{RESULTS}

\subsection{CRL-12445 and CRL-12444 Cells Differed in Their} Growth, Metabolism and Secretion Capacity. CRL12444 and CRL-12445 cells, which secrete a mAb against human IL-8, were chosen as CHO cell models for differential proteomic comparison of the CSP. Prior to the proteomic analysis, these cells were characterized in terms of viable cell concentration, viability, metabolites, and $\mathrm{mAb}$ production. The growth curves and metabolite profiles are presented in Figure 2 , while $\mathrm{pH}$ and ions profiles are shown in Figure S1. The calculated kinetics parameters are presented in Table 1. The lower producer CRL-12444 cells displayed a significantly higher specific growth rate $(\mu)(p<0.01)$, maximum cell concentration $\left(X_{\max }\right)(p<0.05)$, and a lower doubling time $\left(t_{\mathrm{D}}\right)(p<0.01)$ (Figure 2A and Table 1$)$. In congruence with this faster cell growth, this cell line showed a $16.5 \%(p<0.05)$ and $38.3 \%(p<0.01)$ increment in glucose consumption $\left(q_{\mathrm{Glc}}\right)$ and lactate production $\left(q_{\mathrm{Lac}}\right)$, respectively, that translated to a 1.18 times higher lactate/glucose apparent yield $\left(Y_{\mathrm{Lac} / \mathrm{Glc}}{ }^{\prime}\right)(p<$ 0.001) (Table 1). For these same cells, production rates of glutamate $\left(q_{\mathrm{Glu}}\right)$ and ammonium $\left(q_{\mathrm{NH}_{4}}{ }^{+}\right)$were also increased by $3.3(p<0.001)$ and $1.8(p<0.001)$ times, respectively (Figure $2 \mathrm{E}-\mathrm{F}$ and Table 1 ), and glutamine was almost depleted at day 6, while a $3.29 \mathrm{mM}$ concentration remained in CRL-12445 cell supernatants at this time (Figure 2D). Concentration of free glutamine was the net result of cellular import of the dipeptide alanyl-glutamine, its cleavage by peptidases, the incorporation of glutamine into cellular reactions, and its secretion to the medium. ${ }^{40}$ Thus, given that the biochemical analyzer only quantifies free glutamine,
Table 1. Kinetic and Stoichiometric Parameters of CRL12444 and CRL-12445 Cells

\begin{tabular}{lll}
\multicolumn{1}{c}{ Parameter } & \multicolumn{1}{c}{ CRL-12444 } & \multicolumn{1}{c}{ CRL-12445 } \\
$\mu^{a}\left(\mathrm{~h}^{-1}\right)^{* *}$ & $0.031 \pm 0.002^{g}$ & $0.024 \pm 0.001$ \\
$t_{\mathrm{D}}{ }^{b}(\mathrm{~h})^{* *}$ & $22.6 \pm 1.1$ & $28.5 \pm 0.7$ \\
$X_{\mathrm{max}}\left(10^{6} \mathrm{cells} / \mathrm{mL}\right)^{c *}$ & $5.73 \pm 0.57$ & $4.65 \pm 0.10$ \\
$q_{\mathrm{Glc}}{ }^{d}\left(\mu \mathrm{mol} / 10^{6} \mathrm{cells} *\right.$ day $) *$ & $-3.17 \pm 0.26$ & $-2.72 \pm 0.05$ \\
$q_{\mathrm{Lac}}\left(\mu \mathrm{mol} / 10^{6} \mathrm{cells} *\right.$ day $) * *$ & $4.15 \pm 0.32$ & $3.00 \pm 0.15$ \\
$Y_{\mathrm{Lac} / \mathrm{Glc}}{ }^{\prime}(\mathrm{mol} / \mathrm{mol})^{e * * *}$ & $1.31 \pm 0.01$ & $1.11 \pm 0.04$ \\
$q_{\mathrm{Glu}}\left(\mu \mathrm{mol} / 10^{6} \mathrm{cells} *\right.$ day $) * * *$ & $0.20 \pm 0.01$ & $0.06 \pm 0.01$ \\
$q_{\mathrm{NH}_{4}}{ }^{+}\left(\mu \mathrm{mol} / 10^{6}\right.$ cells*day $) * * *$ & $0.92 \pm 0.06$ & $0.50 \pm 0.03$ \\
$q_{\mathrm{Ca}^{2+}}\left(\mathrm{nmol} / 10^{6} \text { cells*day }\right)^{*}$ & $-2.57 \pm 0.18$ & $-4.27 \pm 0.72$ \\
$q_{\mathrm{p}}{ }^{f * * *}$ & $1.0 \pm 0.11$ & $25.6 \pm 1.5$
\end{tabular}

${ }^{a}$ Specific growth rate. The asterisks indicate parameters that were significantly different $(*: p<0.05, * *: p<0.01$, and $* * *: p<0.001 ; t$ test). ${ }^{b}$ Doubling time. ${ }^{c}$ Maximum cell concentration. ${ }^{d}$ Specific consumption $(-)$ or production $(+)$ rate. ${ }^{e}$ Lactate/glucose apparent

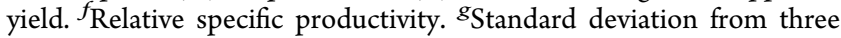
biological replicates.

specific alanyl-glutamine consumption rate could not be determined and other techniques such as chemical derivatization coupled to liquid chromatography should be used for this purpose. ${ }^{41}$ Consumption or production rates of metabolites were in full agreement with values reported for adherent and suspension $\mathrm{CHO}$ cells, cultured in T-flasks, Erlenmeyer flasks, and bioreactors, under batch, fed-batch, or chemostat conditions. $^{4,42-49}$ The $95 \%$ confidence interval of mean of $q_{\mathrm{Glc}}\left[-(2.02-4.33) \mu \mathrm{mol} / 10^{6}\right.$ cells $*$ day $\left.)\right], \mathrm{q}_{\mathrm{Lac}}(2.54-7.18$ $\mu \mathrm{mol} / 10^{6}$ cells $*$ day), $Y_{\mathrm{Lac} / \mathrm{Glc}}^{\prime}(1.01-1.70 \mathrm{~mol} / \mathrm{mol})$, and $q_{\mathrm{NH}_{4}{ }^{+}}$ 
A

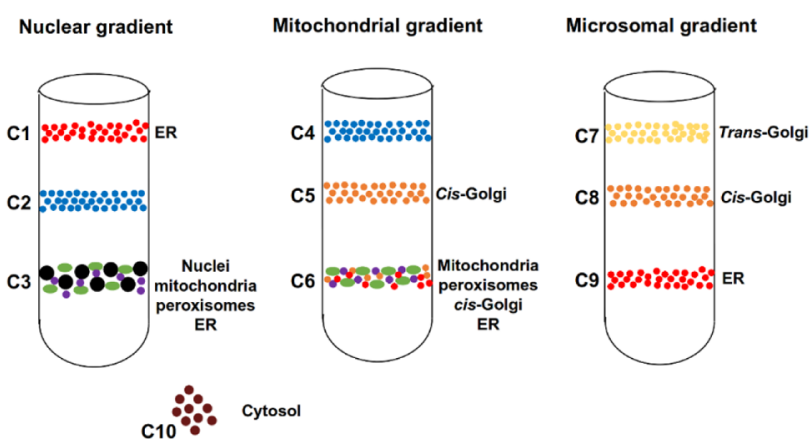

B

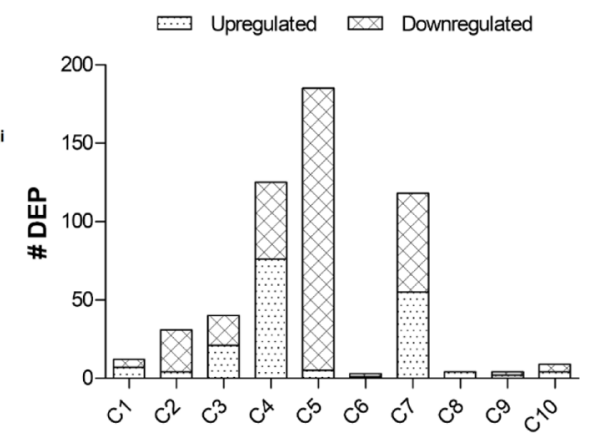

Figure 3. Proteins with differential expression by cellular compartment. (A) Subcellular compartments (C1-C10) obtained by differential and isopycnic centrifugation from cell homogenates. (B) Number of DEPs identified for each compartment by SAM and ROTS algorithms, which were upregulated or downregulated in the higher producer CRL-12445 cells.

$\left(0.17-1.88 \mu \mathrm{mol} / 10^{6}\right.$ cells*day) of all those reports comprises the values obtained in this study. Glutamate can be consumed or secreted in dependence on the medium and additives employed. ${ }^{4,42,44,47,49}$ In our case, glutamate was exported to the medium and its production rate $\left(q_{\mathrm{Glu}}\right)$ was in accordance with other $\mathrm{CHO}$ cell clones. ${ }^{4,44}$

No differences were observed in profiles of $\mathrm{pH}$, sodium and potassium, at any time point, while calcium was consumed by both cells (Figure S1). Calcium consumption rate $\left(q_{\mathrm{Ca}}{ }^{2+}\right)$ of CRL-12445 cells was superior to that of CRL-12444 cells $(p<$ 0.05 ) (Table 1). MAb $q_{p}$ of CRL-12445 (higher producer) cells was 26 times higher in average than that of CRL-12444 (lower producer) cells $(p<0.001)$ (Table 1$)$, allowing these two cell populations to be used for differential subcellular proteomics analysis in order to identify proteins and suggest cellular processes linked to changes in RP productivity.

2.2. MAb from Both Cell Lines Showed a Similar Biological Activity. To analyze whether a 26-fold difference in $\mathrm{q}_{\mathrm{p}}$ between both cell lines would affect the biological activity of secreted $\mathrm{mAb}$, its binding to human IL-8 was assessed by Western blot (WB). For this purpose, antibody was affinitypurified to homogeneity, as confirmed by the presence of only light and heavy chains on reducing SDS-PAGE (Figure S2A). Non-reducing SDS-PAGE revealed four protein bands (Figure S2B), probably corresponding to different assemblies of light and heavy chains. Antibody from both cell lines strongly recognized monomers $(10-15 \mathrm{kDa})$, dimers $(15-25 \mathrm{kDa})$, and trimers $(\approx 35 \mathrm{kDa})$ of recombinant IL-8 obtained in Escherichia coli lysates (Figure S2C-E), as expected. These results suggested that in spite of $q_{\mathrm{p}}$ changes, the folding state and antigen recognition of secreted $\mathrm{mAb}$ were not noticeably different between both cell lines, which indicates that in this case, productivity differences did not alter those structural properties of $\mathrm{mAb}$ directly linked to antigen recognition.

2.3. Around $10 \%$ of All Identified Proteins Were Differentially Expressed between Both Cell Lines. In order to capture the CSP subproteome, subcellular organelles from both cell lines were isolated by mechanical disruption followed by their separation in sucrose gradients, from which proteins were precipitated and subjected to shot-gun proteomics (Tables S1-S2). After data processing, 4952 protein groups were identified covering about 59\% of all proteins reported from two $\mathrm{CHO}$ cell lines and seven tissues of Chinese hamster. ${ }^{50}$ In addition to $\mathrm{CHO}$ cell proteins, the concentration of $\mathrm{mAb}$ light chain in subcellular compartments containing endoplasmic reticulum (ER) $(\mathrm{C} 1, \mathrm{C} 3$, and $\mathrm{C} 9)$ was also measured and used as an internal control of protein expression levels between both cell lines. In agreement with measured $q_{\mathrm{p}}$, intracellular mAb was higher in CRL-12445 cells than in CRL-12444 cells in all cases, showing statistical significance for $\mathrm{C} 1$ and $\mathrm{C} 3$ compartments (Figure S3, $p<$ $0.05)$. Before proceeding with differential expression analysis, a correlation test was done to assess the relationship between each pair of biological replicates. As a result of analysis, all replicates were significantly associated $(p<0.001)$, and the Pearson's coefficient $\left(R^{2}\right)$ was equal or superior to 0.79 , indicating a positive correlation and that the replicates behaved very similarly. 80 and $70 \%$ of samples from CRL-12444 and CRL-12445 cells, respectively, showed a $R^{2} \geq 0.90$ (Figures S4-S7).

In the higher producer CRL-12445 cells, SAM algorithm identified 125 upregulated and 285 downregulated proteins in comparison with the lower producer CRL-12444 cells, whereas ROTS reported 66 upregulated and 71 downregulated ones, accounting for a total of 493 DEPs that represent $10 \%$ of all identified proteins (Table S3). A group of 21 upregulated and 25 downregulated proteins were simultaneously detected by both algorithms (hereinafter shared upregulated or downregulated proteins). Besides the whole analysis of all DEPs, the contribution of each subcellular compartment (C1-C10, Figure $3 \mathrm{~A}$ ) to their identification was also examined (Figure 3B). Most DEPs came from compartments C3-C5 and C7, which are mainly enriched in Golgi Apparatus, nuclei, mitochondria, peroxisomes, and $\mathrm{ER},{ }^{, 1}$ showing an overrepresentation of proteins from the CSP. Upregulated proteins were positioned principally in an unidentifiable compartment (C4) and trans-Golgi, while downregulated ones were highly enriched in cis-Golgi.

2.4. Gene Ontology Analysis, Modified Pathways, and Enrichment of Gene Groups from DEPs. DEPs were classified according to gene ontology (GO) enrichment analysis through PANTHER, DAVID, and KEGG tools to determine which categories were over- or under-represented in the higher producer CRL-12445 cell line. By using PANTHER gene list analysis, shared upregulated (Figure S8A,C,E,G,I) and downregulated (Figure S8B,D,F,H,J) proteins pointed out to differences in metabolism, organization, location, or biogenesis of cellular components, and other cellular processes (Figure S8A,B), that were tracked to cells and protein-containing complexes and organelles (Figure S8C,D). Membrane proteins were upregulated while those from supramolecular complexes and extracellular regions were downregulated. Although central 


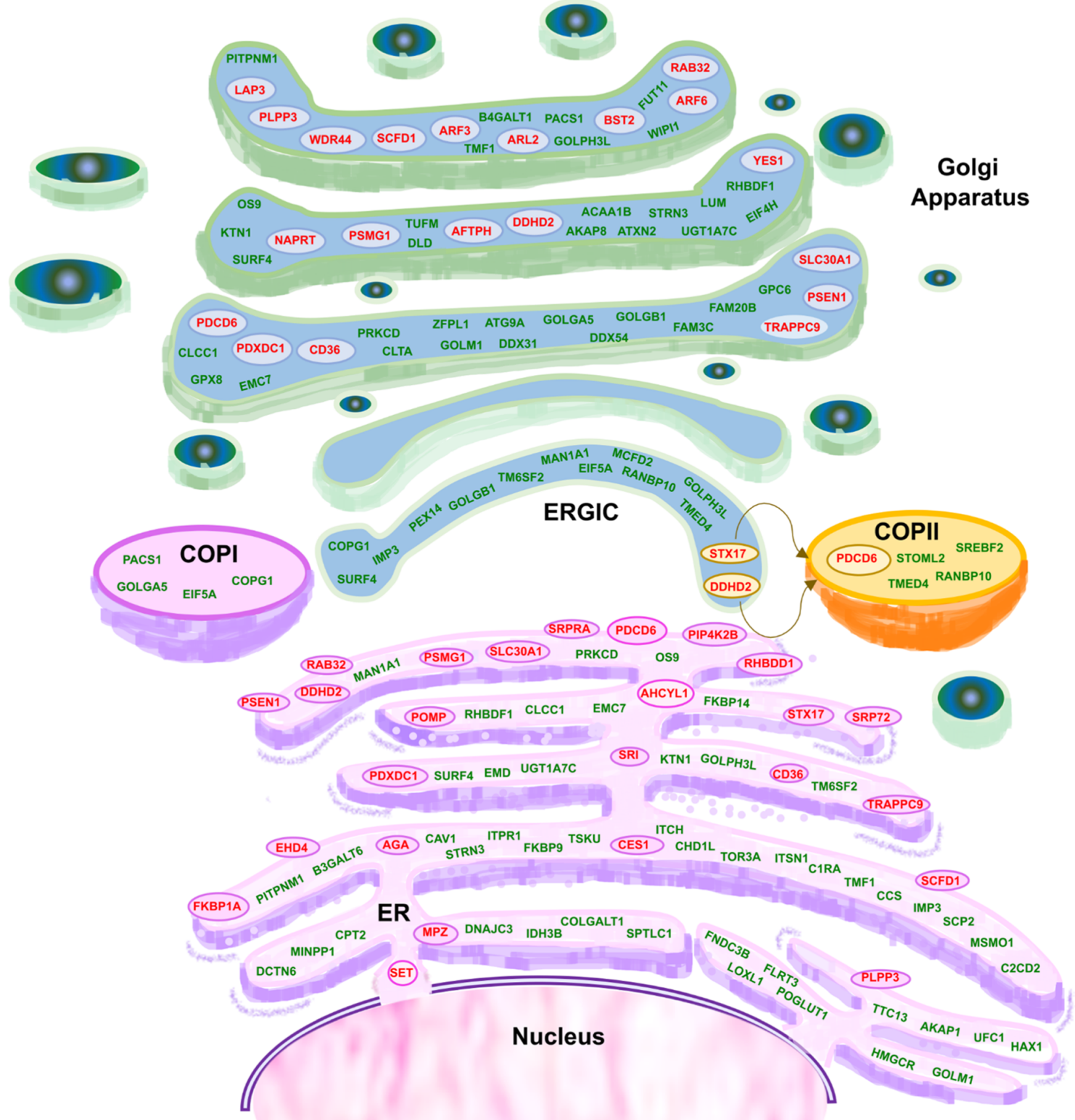

Figure 4. Mapping of all DEPs to the CSP. Upregulated (red) and downregulated (green) proteins were mapped to organelles by using GO terms from Uniprot and DAVID and by matching with mouse database from COMPARTMENT. COPI/II: coat complex protein I/II vesicle, ER: endoplasmic reticulum, ERGIC: ER-Golgi intermediate compartment, SV: secretion vesicle, and PM: plasma membrane.

carbon pathways (glycolysis and pyruvate metabolism) were disturbed in both cells, the enrichment of tricarboxylic cycle indicated an improved oxidative metabolism in the higher producer cells $^{52}$ (Figure S8G). Other reduced categories in CRL-12445 cells were proline biosynthesis, signaling molecules, and calcium-binding proteins (Figure S8H,J). Vesicle transport (Figure S9E,F), protein quality control by proteasome, and synthesis of DNA precursors (Figure S9G) were other functions positively associated to the higher producer cells, while cytoskeleton regulation by Rho GTPase and formyltetrahydroformate biosynthesis were negatively linked to this phenotype (Figure S9H). In addition to the gene list analysis of PANTHER, the over-representation test indicated that CRL-12445 cells increased protein translation and ER-to-i anterograde transport, while protein representation of ribonucleoprotein-associated processes and fatty acid oxidation was reduced (Tables S4-S13).

In agreement with an active oxidative metabolism and cytoskeleton rearrangement, the NAD metabolism (Figure S10A) and Rac GTPase-binding (Figure S10E) were new 
categories found, as upregulated in CRL-12445 cells by DAVID analysis. Conforming to the DAVID functional annotation tool, transport, secretion, endocytosis, lipid storage, actin polymerization, synthesis of ribose phosphate and ascorbic acid, proteasome, autophagosome, lysosomes, and endosomes were also upregulated (Table S14), while calcium transport, RNA splicing, and peroxisomes were downregulated (Table S15).

Besides GO terms, the differences in cellular pathways were explored through KEGG (Figure S11). A closer inspection to these reconstructed pathways exposed that pentose phosphate pathway, aminoacyl-tRNAs, RNA degradation, ABC transporter, actin cytoskeleton, and cholesterol metabolism were positively associated to higher producer cells, while oxidative phosphorylation, fatty acid degradation, nucleotide metabolism, transcription, ribosomes, ER folding, and cell adhesion were repressed (Table S16).

GSEA analysis revealed that gene sets corresponding to metabolism and transport of amino acids, cell growth, DNA repair, endocytosis, extracellular matrix (ECM) organization, glycosylation, vesicle-mediated transport, purine metabolism, and response to ROS were highlighted in the higher producer cells. On the contrary, transcription, processing, and splicing of RNAs, ribosome biogenesis, and response to ER stress were diminished (Tables S17-S19).

In line with our results, earlier omics studies suggest that during RP synthesis, $\mathrm{CHO}$ cells activate vesicle transport and DNA protection and modify their metabolism of carbohydrates, lipids, and amino acids, to increase protein secretion and energy availability and to avoid ROS-induced damage. ${ }^{15,18-24,53,54}$ The increment of productivity appears to be mediated by a higher transcription, chromatin remodeling, translation, and protein catabolism. ${ }^{15,19,24,53}$ In general, higher producer cells tend to diminish proteins participating in cell proliferation, and their cytoskeleton undergoes a rearrangement. Frequently, the abundance of cytoskeleton regulatory proteins changes, causing the restructuring of the filaments and microtubules that could promote vesicle-mediated transport. $^{15,22,24}$ The regulation of intracellular calcium and calcium-dependent responses, ${ }^{20,24,54}$ annexin-dependent responses, ${ }^{21}$ and activity of MAP kinases, ${ }^{20,53}$ Ras, $^{53}$ insulin, ${ }^{55}$ G proteins, Rho GTPases, phosphatases, and nuclear receptors ${ }^{24}$ has been associated with an enhancement of RP production, as discussed in the Supporting Information.

2.5. Relevant New DEPs Involved in RP Production Were Identified by the Subcellular Fractionation Strategy Compared to Previous Whole CHO Cell Proteomics. The DEPs were compared with those reported in previous studies where $\mathrm{q}_{\mathrm{p}}$ was used as a differentiation criterion between various cell lines (Tables S20-S21), ${ }^{18-24}$ in order to identify common targets relevant for $\mathrm{RP}$ production and to compare the detection capabilities between the subcellular fractionation strategy and the classical whole cell proteomics approaches. Only 33\% of upregulated proteins were present in previous reports, whereas this percentage was even lower $(17 \%)$ for the downregulated ones. The large number of unmatched proteins with preceding reports draws attention to the high percentage of new targets provided in this study, which are possibly related to the improvement of RP productivity in $\mathrm{CHO}$ cells. In this sense, subcellular proteomics strategy can be considered as an alternative to classical proteomics to explore the molecular traits of $\mathrm{CHO}$ cells, which are associated to a higher production phenotype.
2.6. One-Third of DEPs Belonged to the CSP. Given that the CSP has been recognized as a bottleneck for protein production in mammalian cells, ${ }^{56-58}$ all DEPs were mapped to organelles of this cellular route, to elucidate which molecular processes taking place along the secretory pathway could contribute to differences in $\mathrm{q}_{\mathrm{p}}$ between both cell lines (Figure 4). Mapping of mouse orthologues was based on manual search in the literature, Uniprot, DAVID, and GeneCards resources and by matching with the mouse database from COMPARTMENT (Tables S22-S25). ${ }^{59}$ Interestingly, on average one-third of all DEPs were assigned to the secretory pathway, of which $21 \%$ were upregulated and $79 \%$ were downregulated, and most of them have not been identified in previous whole cell proteomic studies ${ }^{18-24}$ (68\% from upregulated and $87 \%$ from downregulated targets). These proteins were mainly located to ER (74\% upregulated and $67 \%$ downregulated) and Golgi apparatus (59\% upregulated and $54 \%$ downregulated). About $23 \%$ of all DEPs from the microsomal gradient belonged to the secretory pathway, and around $27 \%$ of all DEPs mapped to this pathway came from the microsomes. The changes in cellular levels of this subset of DEPs could positively impact translation, folding, traffic, and modifications of RP along the secretory pathway and will shed light on processes from this pathway related to RP expression.

\section{DISCUSSION}

The present study used subcellular proteomics to analyze the differential expression of proteins from the CSP of two cell lines with a 26-fold difference in their $\mathrm{mAb} q_{\mathrm{p}}$, in order to identify possible bottlenecks for protein production in $\mathrm{CHO}$ cells, with special attention to the secretory pathway, which has been identified as one of the principal barriers during RP production in mammalian cells. ${ }^{25-27,56-58}$ Despite differences in $q_{\mathrm{p}}$, the lower (CRL-12444) and higher (CRL-12445) producer cells showed a comparable biological activity of $\mathrm{mAb}$, assessed by antigen recognition in a WB assay (Figure S2), indicating that the differences in $q_{\mathrm{p}}$ did not alter $\mathrm{mAb}$-binding capacity in these $\mathrm{CHO}$ cell clones. Unfortunately, experiments that analyze the influence of $q_{\mathrm{p}}$ on $\mathrm{mAb}$ binding are scarce or non-existent.

Though lack of correlation between $\mu$ and $q_{\mathrm{p}}$ has been reported for a panel of recombinant $\mathrm{mAb}$ expressing $\mathrm{CHO}$ subclones, ${ }^{60}$ other studies have documented an inverse relationship between these variables on batch and chemostat cultures, ${ }^{61-63}$ which is coincident with our work (Table 1 ). It could be suggested that at higher growth rates, there is an increasing demand for energy and biomolecule precursors for biomass synthesis, which compromises the cellular resources for RP production. In line with this explanation, a higher $X_{\max }$ $(p<0.05)$ was reached by the lower producer and faster growing CRL-12444 cells in comparison to CRL-12445 cells, similar to what has been reported for a ht-PA producing cell line. ${ }^{63}$ On the contrary, at lower $\mu$ values, a greater proportion of resources can be used for mAb production in CRL-12445 cells, resulting in a significantly higher $q_{\mathrm{p}}(p<0.001)$.

In order to capture the cellular processes from the CSP that could be limiting for protein production, a subcellular fractionation protocol was applied to cells collected during the exponential growth phase, ${ }^{51}$ from which 10 subcellular compartments were isolated and their proteins submitted to shot-gun proteomics. This subcellular proteomics strategy led to the identification of 493 DEPs, of which around $80 \%$ have not been described as relevant for protein production, 


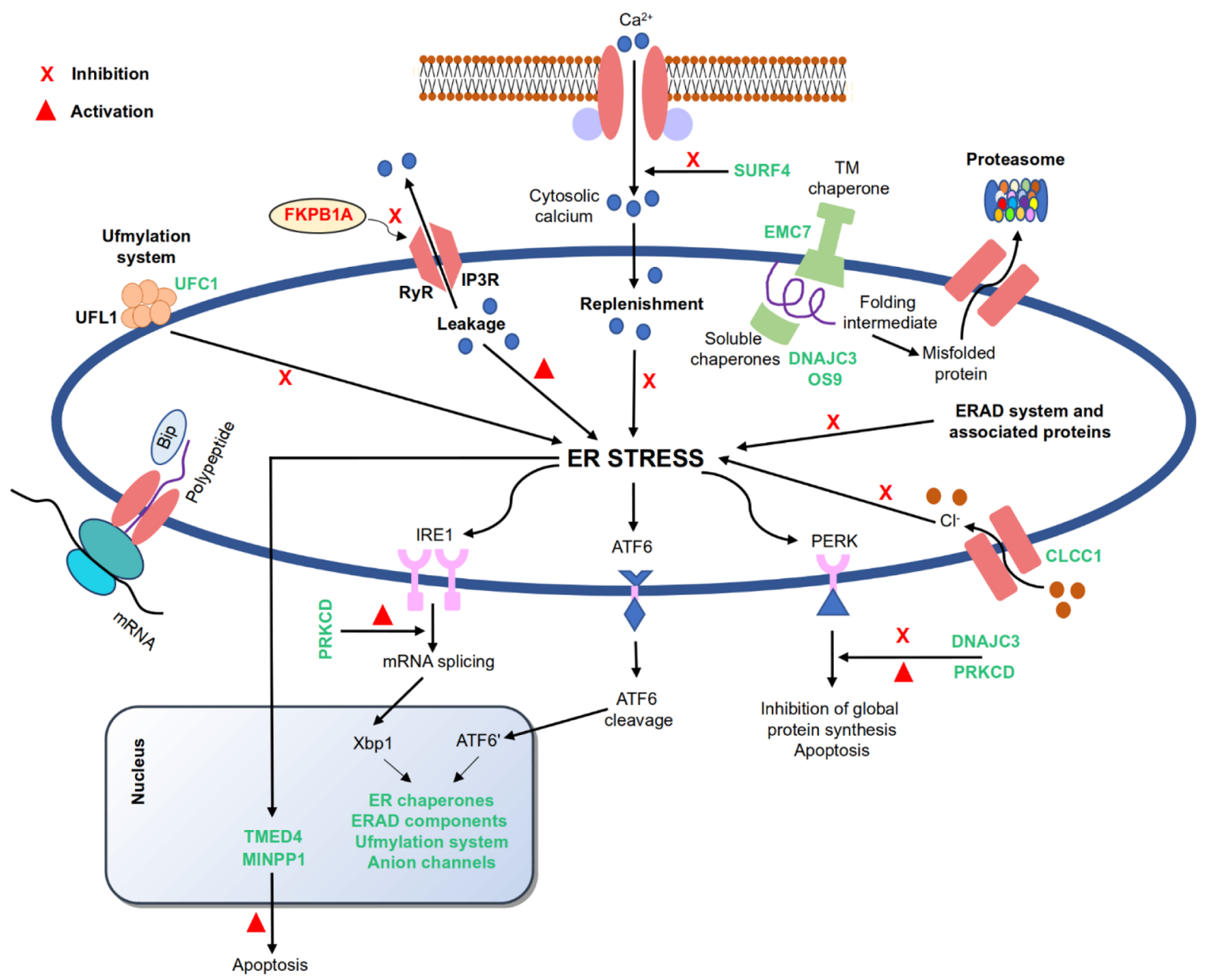

Figure 5. Homeostasis and stress of ER and UPR. Downregulated (green) and upregulated (red) proteins belonging to this category inhibited or activated various molecular processes that could lead to, suppress, or be triggered by ER stress. ER: endoplasmic reticulum, ERAD: ER-associated degradation, and TM: transmembrane.

providing hundreds of new targets that can be modified in $\mathrm{CHO}$ cells. This high number of new targets reflects the potential of subcellular proteomics over classical approaches to increase proteome coverage and the identification of low abundance cellular proteins. ${ }^{30,31,33}$ Actually, the 59\% proteome coverage of this study exceeds that achieved in other differential proteomic studies $(5-31 \%)^{18,20-22}$ which reinforces the importance of subcellular fractionation prior to proteomics to allow enrichment of low abundance of proteins, such as those from the CSP and mitochondria. ${ }^{30,51}$ The fact that one-third of all DEPs were assigned to the CSP (Figure 4) supports the use of this technique and highlights the large number of molecular processes from the secretory pathway that can be considered as a limiting factor for RP production in these cells. It is noteworthy that a quarter of all DEPs came from the microsomal gradient (Figure 3), demonstrating the potential of this novel sucrose gradient to study the CSP of mammalian cells. ${ }^{51}$

To comprehensively understand the biological processes associated to a higher producer phenotype, the DEPs from the CSP were grouped into eight different categories according to their known functions in protein production in this pathway (21 downregulated and 13 upregulated proteins). Additional discussion about metabolism of carbon, nitrogen, nucleic acids, proteins, cofactors, vitamins, cytoskeleton organization, and cell signaling is provided in the Supporting Information.

3.1. ER Stress and Unfolded Protein Response. ER stress and unfolded protein response (UPR) comprise eight (CLCC1, DNAJC3, EMC7, OS9, MINPP1, TMED4, UFC1, and PRKCD) and two (PITPNM1 and SURF4) proteins directly or indirectly involved in these processes, respectively (Figure 5). CLCC1 is a chloride permeable channel with low expression in $\mathrm{CHO}$ cells ${ }^{64}$ whose loss increases sensitivity to ER stress and triggers an UPR. ${ }^{65}$ Its decrease in the higher producer cells could be a consequence of the absence of ER stress and UPR, and of a higher folding capacity of this cell line, explanation that could also be applied to the downregulation of DNAJC3, EMC7, OS9, and UFC1. The UPR increases the amount of DNAJC3 in ER lumen, ${ }^{66-68}$ where it functions as a co-chaperone with HSP40 and HSC70. ${ }^{69}$ Another UPR-induced chaperone is EMC7, a subunit of the EMC complex that participates in ER-mitochondria tethering, folding of transmembrane proteins, ${ }^{70-72}$ and disposal of misfolded proteins by interaction with ER-associated degradation (ERAD) machinery. ${ }^{73}$ OS9 expression has also been increased after an UPR, ${ }^{74,75}$ which favors the degradation of glycosylated and retention of non-glycosylated substrates, $^{74,76,77}$ stabilizes the ERAD SEL1/HRD1 complex ${ }^{77}$ and functions in complex with $\mathrm{BiP}$ and GRP94 chaperones 


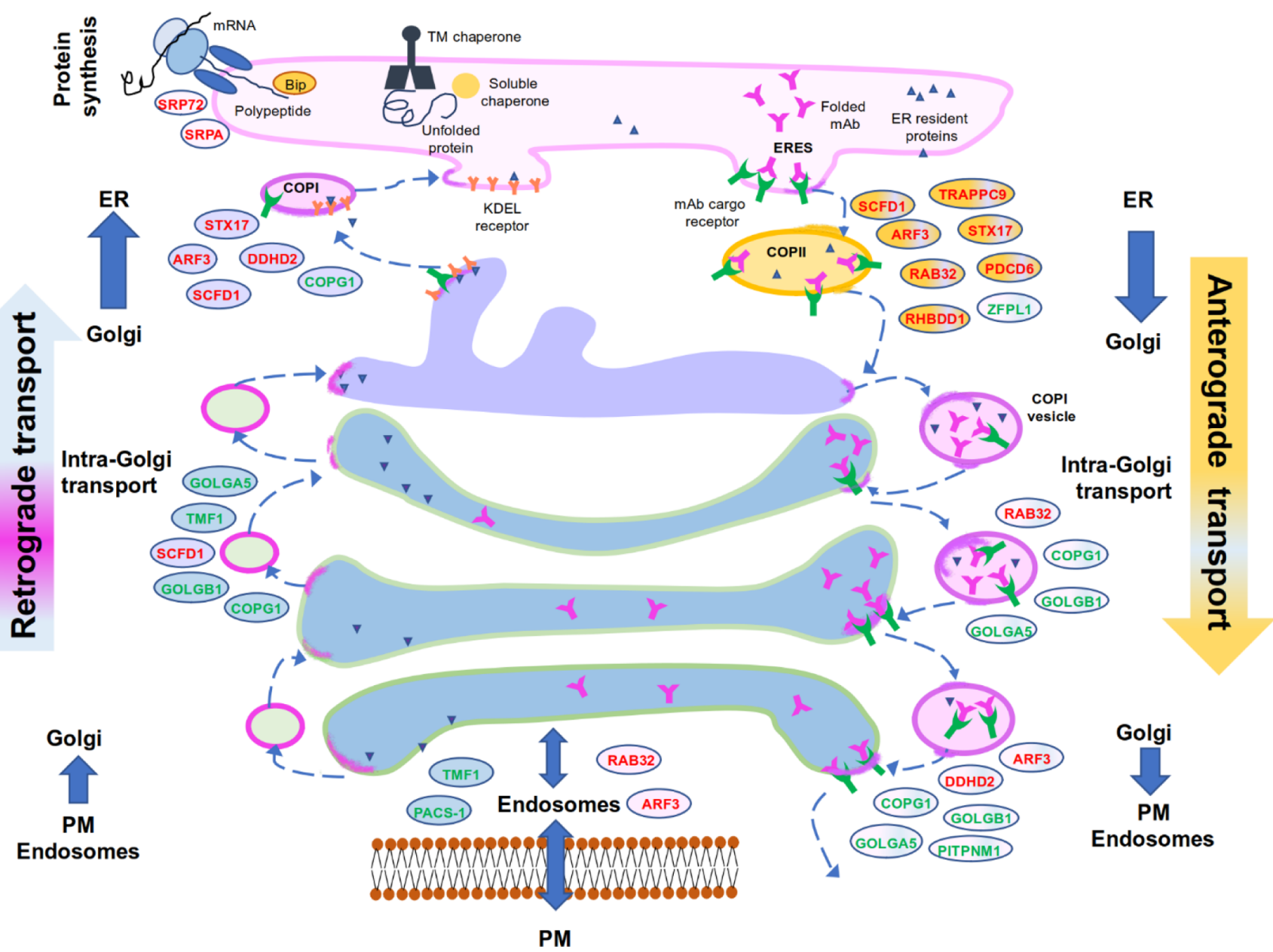

Figure 6. Affected targets involved in protein synthesis, translocation into ER lumen, and vesicle-mediated traffic throughout the secretory pathway. Upregulated (red) and downregulated (green) targets were shown. Arrows indicated the direction of the transport. PM: plasma membrane, ER: endoplasmic reticulum, TM: transmembrane, mAb: monoclonal antibody, ERES: ER exit sites, and ERGIC: ER-Golgi intermediate compartment.

during protein folding. ${ }^{76}$ UFC1 mediates ufmylation of various cellular targets and, although the biological function of this post-translational modification (PTM) is poorly understood, $^{78-80}$ its known that ER stress increases the formation of ufmylation complex and, congruently, blocking ufmylation leads to ER stress. ${ }^{81}$

In the case of PRKCD, this protein kinase is recruited to ER membranes and stress fibers upon activation, where it is required for a full development of UPR and apoptosis. ${ }^{82-85}$ MINPP1 and TMED4 are involved in maintaining a functional apoptosome, and their cellular amounts increase as a result of ER stress. ${ }^{86,87}$ As a consequence of this same stress, PITPNM1 assembles into a phosphorylated PYK2/PITPNM1 complex that plays a role in calcium- and phosphoinositide-dependent signaling pathways, ${ }^{88}$ and SURF4 initiates or maintains UPR by preventing calcium from entering the cell. ${ }^{89}$ The downregulation of all proteins from this category supports the hypothesis that the higher producer cells have not develop an ER stress, UPR, or stress-dependent apoptosis, probably because their maximum folding capacity has not been reached yet. Among the preceding omics comparing $\mathrm{CHO}$ cell populations with different RP production, only one transcriptomic study suggested the upregulation of UPR and ERAD, ${ }^{54}$ which was not subsequently confirmed by the proteomic study of these same cells, ${ }^{15}$ similar to our results. It should be noted that in particular cell lines, the combination of intrinsic physicochemical properties of an $\operatorname{IgG}$ and a deficient ER export machinery can activate a full UPR. ${ }^{25}$

3.2. Homeostasis of ER and Golgi Apparatus. Seven downregulated proteins were implicated in this group (CLCC1, EMC7, UFC1, PITPNM1, TMF1, GOLPH3L, and GOLGA5). The functions of CLCC1, EMC7, and UFC1 in organelle homeostasis are linked to their role in protein folding, ER stress, and UPR, while the changes in the remaining four proteins affect the Golgi structure (Figures 5 and 6). PITPNM1, a phosphatidylinositol (PI)-transfer protein, maintains the Golgi morphology by regulating diacylglycerol homeostasis, ${ }^{90}$ and the depletion of golgin and Rab interacting protein TMF $1^{91,92}$ leads to changes in stacking of Golgi cisternae. ${ }^{91,93}$ GOLPH3L overexpression induces Golgi compaction, while its depletion has opposite effects, demonstrating its function in the Golgi morphology. ${ }^{94}$ The golgin GOLGA5 affects dramatically Golgi morphology, probably as a side effect of its functions in vesicle transport. ${ }^{95}$ Its downregulation leads to fragmentation ${ }^{95}$ or dramatic loss ${ }^{96}$ of Golgi membranes, while its overexpression could stabilize Golgi structure $^{97}$ or induce Golgi ribbon fragmentation. ${ }^{96}$

On the other hand, five upregulated members (DDHD2, RHBDD1, SCFD1, STX17, and FKBP1A) were also classified in this category (Figures 5 and 6). SCFD1 and STX17 function in maintaining the Golgi apparatus structure by their role in protein traffic, ${ }^{98,99}$ with knockdown of STX17 causing 
disruption of the ER-Golgi intermediate compartment (ERGIC), fragmentation of Golgi apparatus, and a disturbed COPI vesicle localization. ${ }^{98}$ The role of DDHD2 in the structure and functions of the secretory pathway remains controversial, insomuch as its knockdown does not affect the Golgi structure, ${ }^{100}$ but its overexpression can result in Golgi dispersion and aggregation of ER and ERGIC ${ }^{101,102}$ or no morphological changes at all. ${ }^{103}$ RHBDD1 preserves ER homeostasis by aiding at disposal of misfolded transmembrane proteins, ${ }^{104}$ and FKBP1A, a cytosolic isomerase, by stabilizing RyR and IP3R calcium receptors, ${ }^{105,106}$ preventing in this way calcium leakage from ER lumen. The adjustment in the cellular concentration of proteins of this category suggests the presence of morphological changes in the CSP that are associated with differences in $q_{\mathrm{p}}$ between both cell lines, while maintaining at the same a proper CSP structure for synthesis, traffic, and modifications of recombinant and self-proteins.

3.3. Anterograde and Retrograde Transport. This category comprises seven downregulated proteins (PITPNM1, ZFPL1, GOLGB1, GOLGA5, PACS-1, TMF1, and COPG1) that participate in different transport routes (Figure 6). Downregulation of PITPNM1 inhibits export of plasma membrane (PM) proteins and glycosaminoglycans from the trans-Golgi network (TGN). ${ }^{90}$ ZFPL1 mediates ERGIC to cisGolgi transport of cell surface proteins, probably by acting as a tethering factor. ${ }^{107}$ GOLGB1, with an analogous function to ZFPL1, mediates retrograde transport, ${ }^{108}$ maintenance of Golgi resident proteins, ${ }^{109,110}$ and anterograde transport of ECM components ${ }^{111}$ and PM proteins. ${ }^{112}$ GOLGA5, another tethering factor ${ }^{95,113}$ and a RAB1 effector, ${ }^{96,97}$ participates in intra-Golgi retrograde transport ${ }^{95,113}$ and functions partially in anterograde transport of cell surface proteins. ${ }^{96,113}$ TMF1 also functions in intra-Golgi retrograde transport ${ }^{92}$ and has been involved in endosomes to TGN transport. ${ }^{93}$ PACS-1 mediates transport from endosomes ${ }^{14,115}$ and $\mathrm{PM}^{115,116}$ to TGN, and probably works in other post-Golgi transport routes, ${ }^{115}$ through connection of cargoes and adaptor proteins (Figure 6). The downregulation of COPG1 is challenging to explain due to the wide range of transport processes in which COPI vesicles could participate. ${ }^{117-119}$ Since these vesicles are heterogeneous in their composition of $\gamma$ and $\zeta$ subunits, coatamer populations that carry $\gamma 1$ or $\gamma 2$ subunits coexist at the same time in mammalian cells and, therefore, the deficiency of $\gamma 1$ subunit (COPG1) could be rectified by $\gamma 2$ in the higher producer cells. $^{120,121}$ Additionally, only receptor tyrosine kinase nuclear signaling or specific transport routes in the higher producer clone could be affected by COPG1 downregulation. $^{117,118}$

Regarding upregulated targets, eight members (ARF3, DDHD2, PDCD6, RAB32, RHBDD1, SCFD1, TRAPPC9, and STX17) were also included in this transport category (Figure 6). ARF3 is an ADP-ribosylation factor that supports COPI vesicle biogenesis, ${ }^{122,123}$ mediates transport from ER to endolysosomes, ${ }^{124}$ endosome to PM, ERGIC to cis-Golgi, cisGolgi to ER, ${ }^{125,126}$ and TGN to PM, ${ }^{127}$ and is required for the integrity of recycling endosomes. ${ }^{125}$ The role of DDHD2 in the early secretory pathway is controversial, being necessary for Golgi to $\mathrm{PM}^{100}$ or Golgi to $\mathrm{ER}^{103}$ transport. PDCD6 is a calcium-binding protein recruited to ER exit sites (ERES) that participates in formation and trafficking of COPII vesicles by enhancing outer coat recruitment, ${ }^{128}$ loading of cargo and other required proteins, functioning as a cargo receptor for certain substrates, $^{129}$ and recruiting other proteins to
ERES. ${ }^{130,131}$ Its reported upregulation in recombinant $\mathrm{CHO}$ cells in comparison to non-producer cells ${ }^{23}$ validates this protein as a relevant target for $\mathrm{RP}$ expression. RAB32 participates in protein traffic in the late secretory pathway, where it targets LRRK2 to transport vesicles and recycling endosomes, ${ }^{132}$ mediates traffic from endosomes to TGN, ${ }^{133}$ and maintains CI-MPR in endosomes. ${ }^{133}$ RHBDD1 is an ER resident trans-membrane protease that negatively regulates exosome secretion ${ }^{134}$ or facilitates protein secretion in microvesicles by mediating their ER to Golgi transport. ${ }^{135}$ TRAPPC9 is a non-essential subunit of the TRAPP complex that allows shedding of the inner coat from COPII vesicles to facilitate tethering, docking, and fusion of these vesicles with their target membranes. Its binding to $\mathrm{p} 150^{\text {Glued }}$ links vesicle movement along microtubules with tethering, printing a suitable directionality to this movement. ${ }^{136}$ The SNARE STX17 recycles between ER and ERGIC and has demonstrated to be essential for an adequate secretion of proteins ${ }^{137}$ and maintenance of ERGIC and Golgi compartments. ${ }^{98}$ SCFD1 cooperates with SNARE complexes in membrane fusion events, ${ }^{138-140}$ is required for correct targeting of PM and lysosomal proteins, ${ }^{139,141}$ and its overexpression has increased the $\mathrm{q}_{\mathrm{p}}$ of $\mathrm{RP}$ in yeasts ${ }^{142,143}$ and mammalian cells. ${ }^{58}$ It also functions in Golgi to ER traffic ${ }^{99,138}$ and certain intra-Golgi transport steps. ${ }^{99}$

In summary, the transport between ER and Golgi apparatus is highly enhanced in the higher producer cells, while some intra-Golgi transport routes are downregulated for specific and non-mAb-related cargoes. Transport from and to the late secretory pathway seems to be profoundly remodeled to the detriment of PM and ECM proteins, cargoes that could be dispensable during a higher production of a mAb. Endosomesrelated transport and anterograde fusion events also appear to be highly stimulated during a higher RP production.

Omics data have been shown that an increase of $q_{p}$ in different $\mathrm{CHO}$ cell lines leads to a rearrangement of intracellular traffic. An accumulation of adapter proteins (AP2 and AP3), molecular motors (kinesin and myosin), coat subunits (COPA, COPG2, and COPB1), small GTPases (RABs, SAR1A, and ARFs), and proteins related to vesicle formation (PDCD6) and membrane fusion (recognition and anchoring factors, NSF, SNAREs) has been observed. $^{20,22-24,53,54}$ In common with our results, information suggests an increase in biogenesis, transport, recognition, and fusion of vesicles that could contribute to a higher productivity.

3.4. Production of ECM Components and Secretory Cargoes. Downregulated GOLGB1, SURF4, MINPP1, TMED4, FKBP14, GOLM1, PRKCD, PITPNM1, and MCFD2 (Figures 4 and 6) were classified in this category by their positive effect on ECM production. The knockout/ knockdown of GOLGB1 has shown a negative impact on secretion of proteoglycans and proteins involved in their synthesis, collagens, ECM proteins, and glycosaminoglycans. $^{109,111,144}$ This golgin also co-localizes with dymeclin, another protein involved in collagen secretion. ${ }^{145}$ PRKCD and FKBP14 are also directly linked to collagen secretion as the depletion of the former substantially decreases the transcription, transport, and secretion of collagens, ${ }^{146,147}$ while the latter binds to and participates in the refolding of hydroxylated states of collagens. ${ }^{148,149}$ PITPNM1 favors glycosaminoglycans transport from TGN to PM by controlling diacylglycerol accumulation in Golgi apparatus, ${ }^{90}$ and MINPP1 is tightly 
linked to ECM production during the proliferation ${ }^{150}$ or maturation $^{151,152}$ of chondrocytes.

Others targets involved in the secretion of soluble cargoes were also downregulated in the higher producer cells. GOLM1 has been positively correlated with secretion of matrix metalloproteinases MMP-1, 2, 9, and $13^{153-155}$ and participates directly in traffic and secretion of MMP-2 and the extracellular chaperone clusterin. ${ }^{156}$ TMED4 possibly functions in transport of the hormone precursor proopiomelanocortin (POMC) in the intermediate pituitary melanotrope cells of Xenopus laevis. ${ }^{157}$ MCFD2 forms a cargo receptor together with LMAN1 to transport coagulation factors V and VIII from ER to ERGIC and probably alpha1-antitrypsin. ${ }^{158-160}$ SURF4 is implicated in the secretion of a broad range of cargoes that include glycoproteins, ${ }^{161}$ LPP, ${ }^{162}$ and enamel ECM proteins, hormones, and proteases. ${ }^{163}$ Since cargoes carried by SURF4 from ER to Golgi apparatus contain an ER-ESCAPE motif ${ }^{163}$ that it is not present in the light or heavy chains of anti-IL8 $\mathrm{mAb},{ }^{164}$ its lower abundance is unlikely to affect antibody secretion. The downregulation of all these nonessential proteins suggests that the release of cellular resources and their redirecting to the production of $\mathrm{RP}$ are common strategies of the higher producer cells, which could be applied during cell line development through the knockdown or knockout of these extracellular proteins and those related to their production. Indeed, the disruption of up to 14 genes coding for extracellular proteins has been shown to improve cell density, viability, and transient mAb productivity. ${ }^{165}$

3.5. Glycosylation. Glycosylation was represented by four downregulated members in CRL-12445 cells (GOLGB1, ZFPL1, GOLGA5, and TMF1). While GOLGA5 is required for a mature glycosylation pattern of lysosomal and PM proteins, $^{95}$ its relevance for secreted cargoes remains unexplored. GOLGB1 knockdown decreases protein concentration and induces mislocalization of many glycosyltransferases, such as B4GALT1, MGAT1, and ST6GAL1, ${ }^{109}$ and shifts N-glycans toward a high-mannose type in cancer cell lines. ${ }^{110}$ The Oglycosylation appears to be disturbed as well given that TMF1 maintains Golgi localization of GalNAc-T2 $2^{93}$ and knockdown of ZFPL1 decreases O-linked $\mathrm{N}$-acetylglucosamine. ${ }^{166}$ In this context, a carbohydrate analysis of $\mathrm{mAb}$ is necessary to confirm a disturbed glycosylation in detriment to O-glycan and complex $\mathrm{N}$-glycan patterns in the higher producer cells. MAb $\mathrm{N}$-glycosylation occurs mainly at Asn297 in the Fc region, modulating antibody effector functions through binding to $\mathrm{Fc} \gamma$ receptors and complement activation, whereas O-glycosylation occurs at serine and threonine residues without a consensus sequence. ${ }^{167}$ Therefore, since the Fab portion and not the $\mathrm{Fc}$ region of $\mathrm{mAb}$ binds to the antigen, these possible changes in glycosylation patterns of antibodies between both cell lines are not expected to impact IL- 8 binding, as demonstrated by WB (Figure S2D,E). On the contrary, these plausible glycosylation changes are expected to alter $\mathrm{mAb}$ effector functions.

3.6. Autophagy. Autophagy could be activated in the higher producer CRL-12445 cells through downregulation of PRKCD and ZFPL1 and upregulation of RAB32, SCFD1, and STX17. Loss of PRKCD and ZFPL1 triggers autophagy in rat proximal tubular cells ${ }^{168,169}$ and human gastric carcinoma cell lines. ${ }^{166}$ On the other hand, overexpression of RAB32 increases the number of autophagosomes, whereas its knockdown leads to autophagy blockade. ${ }^{170,171}$ SCFD1 is required for transport of lysosomal enzymes from ER to Golgi apparatus and, although its knockdown triggers induction of autophago- somes as a consequence of ER stress and UPR, autophagy does not occur in its absence because of the lack of lysosomal enzymatic activities. ${ }^{141}$ The SNARE STX17 is recruited to autophagosomes upon autophagic stimuli, ${ }^{172,173}$ where it binds to other SNAREs, ${ }^{174}$ mediates the recruitment of protein complexes required for maturation or fusion of autophagosomes, ${ }^{175,176}$ and participates in autophagosome-lysosome fusion. ${ }^{172,174,176}$ Furthermore, STX17 could increase the transcription of proteins involved in lysosomal functions and autophagy. $^{17}$

Autophagy has been described as a survival mechanism of eukaryotic cells to protect themselves from stressful conditions, provide the necessary energy and biomolecule precursors, and remove damaged organelles. ${ }^{178}$ In the case of $\mathrm{CHO}$ cells, this process can be activated by nutrient depletion, hyperosmotic stress, and sodium butyrate addition, ${ }^{178,179}$ conditions that are absent from the exponentially growing cells sampled in this study. Besides a positive impact of autophagy on viability and longevity of cell cultures, ${ }^{180,181}$ its chemical induction by 3 $\mathrm{MA}^{179,182,183}$ or rapamycin ${ }^{180}$ on CHO cells has been associated with an increase of $q_{\mathrm{p}}$ or product titer. After all, a profound study is becoming mandatory to elucidate the relationship between basal autophagy and $q_{\mathrm{p}}$ in recombinant $\mathrm{CHO}$ cells during the exponential growth phase.

3.7. Proteasomal Activity. The upregulation of two critical chaperones, PSMG1 and POMP, that participate coordinately in the assembly and maturation of proteasomes, ${ }^{184-187}$ proposes that the proteasomal activity could be enhanced in the higher producer cells. PSMG1 participates in $\alpha$-ring assembly of proteasomes, prevents premature nuclear translocation of their intermediates, and favors an adequate folding for further interactions. ${ }^{184-186}$ Subsequently, POMP recruits this $\alpha$-ring and the $\beta$ subunits to ER membranes for formation and dimerization of hemi-proteasomes and mediates maturation of $20 \mathrm{~S}$ proteasomes. ${ }^{185,186,188}$ In view of the fact that PSMG1 and POMP are continuously degraded during maturation of $20 \mathrm{~S}$ proteasomes, ${ }^{185,187}$ increased levels of these proteins are required to sustain or increase the proteasomal activity. Their role in maintaining active proteasomes has been essential to sustain cell proliferation, signaling, and anti-oxidant defenses, avoid apoptosis, and support ER homeostasis. ${ }^{188-191}$

3.8. Protein Synthesis and Translocation into ER Lumen. The two upregulated members of this group (SRP72 and SRPA) act coordinately during the synthesis of proteins and their translocation into ER lumen, which indicates a high upregulation of this pathway in the higher producer cells (Figure 6). SRP72 is a member of the signal recognition particle (SRP), a complex that mediates mRNA-ribosome targeting to Sec61 translocon and favors signal peptide removing. ${ }^{192-194}$ SRP72 is also required for nuclear export, stability, and function of SRP. ${ }^{192,194-196}$ SRPA, the $\alpha$-subunit of SRP receptor (SRPR), ${ }^{197,198}$ is a peripheral membrane protein that targets SPR ribosomes to ER membranes through its binding to the $\beta$-subunit of SRPR. ${ }^{197,199}$ Immediately after targeting, GTP is incorporated into the complex, mRNAribosome cargo is transferred to Sec61 for the subsequent translocation of nascent polypeptide into ER lumen, and the SRP-SRPR complex is dissociated. ${ }^{197-199}$ SRPA also favors the SRP pathway for protein translocation by displacing Sec62 from Sec61-Sec62 complexes and making Sec61 available for $\mathrm{SRP}^{200}$ In CHO cells, endogenous levels of SRPA have demonstrated to positively correlate with an increase in productivity of therapeutic mAbs. ${ }^{20}$ Actually, the over- 
expression of most components from the SRP pathway, including SRPA, has substantially increased the $q_{\mathrm{p}}$ of CHO cell clones producing trastuzumab and infliximab, ${ }^{201}$ which is in accordance with the upregulation of proteins from this pathway found in our study.

\section{CONCLUSIONS}

In the present study, a subcellular proteomics strategy was applied to two $\mathrm{CHO}$ cell lines producing a mAb, with a 26 -fold difference in their $q_{p}$, to identify targets from the secretory pathway associated with RP production. Metabolic analysis showed that an efficient consumption of glucose and glutamine, lower production of harmful metabolites, and an improved oxidative metabolism could be used as high productivity markers during clonal selection. Approximately, $80 \%$ of 493 DEPs were recognized as new targets, of which a third was assigned to the secretory pathway, demonstrating a greater capacity of subcellular proteomics to identify low abundance of proteins compared to classical proteomic strategies. Differential proteomic comparison indicated that an overexpression of proteins involved in protein synthesis and translocation into ER lumen, autophagy, proteasomal activity, and vesicular trafficking, and a downregulation of those related to the production of ECM and secretory cargoes, represent viable strategies to increase product titer during cell culture bioprocesses. On the other hand, increased ER stress, UPR, and ERAD were associated with a lower productivity, suggesting that cells showing these traits should be discarded during clone isolation. Restructuring of intra-Golgi transport, morphological changes of secretory pathway, and mAb PTMs need further studies for their validation and understanding. The approach applied in the present work allowed the identification of hundreds of new protein targets that will help to understand the biological processes associated with protein productivity and provided the basis to design new sublines with novel gene modifications and stronger capabilities for RP production. The cellular concentration of those proteins identified in this and previous classical proteomic studies as differentially expressed should be manipulated in future by genetic approaches in recombinant $\mathrm{CHO}$ cells producing $\mathrm{mAbs}$ or other RPs, in order to confirm which of them might impact productivity. Future subcellular proteomics will allow to increase the number of targets related to $q_{\mathrm{p}}$, in comparison to the classical approaches performed until now. This strategy proved to be an effective tool to gain a deeper insight into the molecular processes related to protein production in $\mathrm{CHO}$ cells.

\section{EXPERIMENTAL PROCEDURES}

5.1. Cell Lines and Culture Conditions. Cell lines $\mathrm{CHO}$ DP-12 clone \#1933 CRL-12444 and clone\#1934 CRL-12445, which secrete a $\mathrm{mAb}$ against human IL-8, were acquired from American Type Culture Collection (ATCC) and adapted to growth in CDM4CHO medium. Cells were seeded at $0.50 \times$ $10^{6}$ cells $/ \mathrm{ml}$ in $250 \mathrm{~mL}$ Erlenmeyer flasks with a filling volume of $20 \%$ in CDM4CHO medium (Hyclone, Logan, UT, USA) supplemented with $6 \mathrm{mM}$ stable glutamine (L-alanyl-Lglutamine dipeptide, Biowest LLC, Kansas City, MO, USA), $0.002 \mathrm{mg} / \mathrm{mL}$ Humulin N (Eli Lilly, Indianapolis, IN, USA), and $200 \mathrm{nM}$ methotrexate (Pfizer, New York, NY, USA), at 60 rpm, $37{ }^{\circ} \mathrm{C}$ in a $5 \% \mathrm{CO}_{2}$ atmosphere in a humidified incubator. Cell concentration and viability were recorded every $24 \mathrm{~h}$ by cell counting in a Neubauer chamber using the trypan blue dye exclusion method.

Each biological replicate represents a different frozen vial from a working cell bank. Biological triplicates were used for the kinetic and metabolic characterization of cultures. Two biological replicates, collected during the exponential growth phase $(72 \mathrm{~h})$ from each cell line, were processed for the subcellular proteomic analysis, where each replicate was a pool of nine Erlenmeyer flasks, in order to collect enough cells.

5.2. Quantification of Metabolites, lons, and $\mathrm{pH}$. Concentration of glucose, lactate, glutamine, glutamate, ammonium, sodium, potassium, and calcium, and $\mathrm{pH}$ were measured in supernatants every $24 \mathrm{~h}$ by using BioProfile FLEX2 Automated Cell Culture Analyzer (Nova Biomedical, Waltham, MA, USA). Specific consumption or production rates were calculated from the exponential growth phase as the ratio between the net concentration of analyte and integral viable cell concentration (IVCD), determined as area under curve by trapezium rule using GraphPad Prism Software v5.01 (GraphPad Software, San Diego, CA, USA).

5.3. Quantification of $\boldsymbol{q}_{\mathrm{p}}$. MAb concentration was measured in supernatants every $24 \mathrm{~h}$ by using Human IgG ELISA Quantitation Set (E80-104, Bethyl Laboratories, Inc., TX, USA), according to manufacturer's protocol. SigmaFast OPD substrate (Sigma-Aldrich, Merck KGaA, Darmstadt, Germany) was prepared according to manufacturer's recommendations and incubated at room temperature for $15 \mathrm{~min}$. The reaction was stopped with $10 \%(\mathrm{v} / \mathrm{v}) \mathrm{HCl}$, and the absorbance was recorded at $490 \mathrm{~nm} . q_{\mathrm{p}}$ was calculated from the exponential growth phase as the ratio between the net product titer and IVCD.

5.4. MAb Purification. MAb purification was carried out under native conditions to preserve its biological activity. The $\mathrm{mAb}$ was purified by Protein A-Agarose affinity chromatography (MabSelect SuRe, GE Healthcare Bio-Sciences, USA) from two culture replicates of each cell line. The supernatant was centrifuged, diluted two-fold in equilibrium buffer (150 $\mathrm{mM} \mathrm{NaCl}, 20 \mathrm{mM}$ sodium phosphate, $\mathrm{pH} 7.2), 0.2 \mu \mathrm{m}$ filtered, and loaded into a $5 \mathrm{~mL}$ column at a flow rate of $2 \mathrm{~mL} /$ min. After washing the column with equilibrium buffer until absorbance has reached the baseline, antibody was eluted with $0.1 \mathrm{M}$ sodium citrate $(\mathrm{pH} 3.0)$, neutralized with $5 \%$ (v/v) $1 \mathrm{M}$ Tris $-\mathrm{HCl}(\mathrm{pH} 9.0)$, and extensively dialyzed against phosphate buffer ( $\mathrm{pH} 7.4)(137 \mathrm{mM} \mathrm{NaCl}, 2.7 \mathrm{mM} \mathrm{KCl}$, $\left.8.1 \mathrm{mM} \mathrm{Na}_{2} \mathrm{HPO}_{4}, 1.8 \mathrm{mM} \mathrm{KH}_{2} \mathrm{PO}_{4}\right)$ at $4{ }^{\circ} \mathrm{C}$.

5.5. Human IL-8 Expression in E. coli. BL21(DE3) cells were transformed with IL-8-pMCSG7 plasmid (DNASU Plasmid Repository, Arizona State University, AZ, USA) ${ }^{202}$ and cultured in ampicillin-supplemented $\mathrm{LB}$ medium, at $37{ }^{\circ} \mathrm{C}$ and $150 \mathrm{rpm}$. Expression of human IL-8 was induced with 1 $\mathrm{mM}$ IPTG for $4 \mathrm{~h}$. Next, cells were centrifuged at $8161 \mathrm{~g}$ for 10 min and disrupted by sonication (Soniprep 150, MSE, Heathfield, East Sussex, UK) in lysis buffer (100 mM NaCl, $1 \mathrm{mM}$ EDTA, $50 \mathrm{mM}$ Tris- $\mathrm{HCl} \mathrm{pH}$ 8.0). Homogenates were solubilized in isoelectric focusing (IEF) buffer [7 M urea, $2 \mathrm{M}$ thiourea, 2\% (w/v) CHAPS, $40 \mathrm{mM} \mathrm{DTT}$, clarified by centrifugation, precipitated by acetone, and solubilized again in IEF buffer. Proteins were quantified and subjected to reducing SDS-PAGE.

5.6. Determination of Protein Concentration. Protein concentration was determined by the Bradford method in 96well microplates using Dye Reagent Concentrate (Bio-Rad, Hercules, CA, USA), and bovine serum albumin (GE 
Healthcare Bio-Sciences, USA) was used as standard, according to manufacturer's recommendations. The samples stored in IEF buffer were diluted 5 times in MilliQ water before quantification.

5.7. SDS-PAGE for Analysis of Affinity-Purified $\mathrm{mAb}$ and Human IL-8. Laemmli buffer was added to samples at a final composition of $60 \mathrm{mM}$ Tris $-\mathrm{HCl} \mathrm{pH}$ 6.6, supplemented with $10 \%(\mathrm{v} / \mathrm{v})$ glycerol, $70 \mathrm{mM}$ sodium dodecyl sulfate (SDS), and $0.2 \mathrm{mM}$ bromophenol blue, with (reducing conditions) or without (non-reducing conditions) $2.5 \%$ (v/ v) 2-mercaptoethanol. Next, these samples were boiled at 95 ${ }^{\circ} \mathrm{C}$ for $5 \mathrm{~min}$, with the exception of those stored in IEF buffer, centrifuged at $8161 \mathrm{~g}$ for $5 \mathrm{~min}$, and applied to $7.5,12$, or $15 \%$ SDS-polyacrylamide gels. Page Ruler Prestained Protein Ladder (ThermoFisher Scientific) was selected as the molecular weight (MW) marker. Samples were resolved in a SE260 Mighty Small II Deluxe Mini Vertical Protein Electrophoresis System (Hoefer, Holliston, USA) at $60 \mathrm{~mA}$, using Tris-Glycine $\mathrm{pH} 8.3$ [25 mM Tris, $192 \mathrm{mM}$ Glycine, $0.1 \%(\mathrm{w} / \mathrm{v}) \mathrm{SDS}$ ] as running buffer. Gels were stained with Coomassie Brilliant Blue R250 (Sigma-Aldrich, Merck KGaA, Darmstadt, Germany) and destained in $5 \%(\mathrm{v} / \mathrm{v})$ methanol and $7.5 \%(\mathrm{v} / \mathrm{v})$ acetic acid.

5.8. Protein Precipitation. Proteins from E. coli homogenates and sucrose gradients were precipitated by acetone, as described by Crowell et al. ${ }^{203}$ and Pérez-Rodriguez et al. ${ }^{204}$ Briefly, $\mathrm{NaCl}$ was added at a final concentration of 100 $\mathrm{mM}$, followed by addition of 4 volumes of cold $80 \%(\mathrm{v} / \mathrm{v})$ acetone and overnight incubation at $-20{ }^{\circ} \mathrm{C}$. After centrifugation at $16,000 \mathrm{~g}$ for $25 \mathrm{~min}$, the protein precipitate was washed twice with 4 volumes of cold $80 \%(\mathrm{v} / \mathrm{v})$ acetone and air-dried.

5.9. MAb Binding to Human IL-8 by WB. Activated polyvinylidene fluoride membranes and reduced 15\% SDSPAGE gels, with $30 \mu \mathrm{g}$ of proteins by lane from chemically induced E. coli homogenates, were soaked in transfer buffer [20 $\mathrm{mM}$ Tris, $154 \mathrm{mM}$ glycine, $0.08 \%$ (w/v) SDS, 20\% (v/v) methanol] for $5 \mathrm{~min}$. Protein transfer was carried out in a Trans-Blot SD Semi-dry Transfer Cell (Bio-Rad, Hercules, CA, USA) at $20 \mathrm{~V}$ for $60 \mathrm{~min}$ and verified by Ponceau staining $[0.5 \%(\mathrm{w} / \mathrm{v})$ Ponceau S, $1 \%(\mathrm{v} / \mathrm{v})$ acetic acid]. Membranes were blocked in $3 \%(\mathrm{w} / \mathrm{v})$ skimmed milk and $0.05 \%(\mathrm{v} / \mathrm{v})$ Tween-20 in phosphate buffer for $1 \mathrm{~h}$ and incubated with 5 $\mu \mathrm{g} / \mathrm{mL}$ of purified anti IL-8 antibodies for $2 \mathrm{~h}$. HRPconjugated anti-human antibody was diluted 1200-fold and incubated with membranes for $1 \mathrm{~h}$. Membranes were revealed with $0.05 \%(\mathrm{~m} / \mathrm{v}) 3,3^{\prime}$-diaminobenzidine and $0.001 \%$ of $30 \%$ $\mathrm{H}_{2} \mathrm{O}_{2}$ solution in phosphate buffer.

5.10. Subcellular Fractionation. All protocols for subcellular fractionation comprising cellular disruption and differential and isopycnic centrifugation have been described previously $^{51}$ and are available at dx.doi.org/10.17504/protocols.io.bf9sjr6e and dx.doi.org/10.17504/protocols.io.bgc4jsyw. In brief, cells were suspended in HEPES buffer $(1 \mathrm{mM}$ EDTA, $10 \mathrm{mM}$ HEPES, $\mathrm{pH} 7.4$ ), incubated on ice for $30 \mathrm{~min}$, and broken up with 25 strokes in a Dounce homogenizer. Cold sucrose was added to restore osmolarity at $0.25 \mathrm{M}$, and nuclear, mitochondrial, and microsomal pellets were collected at $3000 \mathrm{~g}$ for $10 \mathrm{~min}, 9000 \mathrm{~g}$ for $15 \mathrm{~min}$, and $100,000 \mathrm{~g}$ for $1 \mathrm{~h}$ at $4{ }^{\circ} \mathrm{C}$, respectively. Supernatant from the last centrifugation step was named cytosol. Pellets were diluted in $0.25 \mathrm{M}$ sucrose and separated in sucrose gradients at $154,693 \mathrm{~g}$ for $3 \mathrm{~h}$ at $4{ }^{\circ} \mathrm{C}$ (Beckman Coulter, IN, USA). 30-60 and 10-60\% sucrose gradients were employed for nuclear and mitochondrial suspensions and for microsomal preparations, respectively. Proteins from all isolated subcellular fractions were acetoneprecipitated and used for MS/MS analysis.

5.11. Mass Spectrometry Analysis. $200 \mu \mathrm{g}$ of precipitated proteins were solubilized in $50 \mu \mathrm{L}$ of guanidine hydrochloride $(\mathrm{GuHCl})$ buffer $[6 \mathrm{M} \mathrm{GuHCl}, 5 \mathrm{mM}$ Tris (2carboxyethyl) phosphine, $10 \mathrm{mM}$ chloracetamide, $100 \mathrm{mM}$ Tris- $\mathrm{HCl}, \mathrm{pH}$ 8.5] and incubated at $99{ }^{\circ} \mathrm{C}$ for $10 \mathrm{~min}$. Of these, $100 \mu \mathrm{g}$ was digested with trypsin for $12 \mathrm{~h}$, after which trifluoroacetic acid was added at $0.5 \%(\mathrm{v} / \mathrm{v})$, and $20 \mu \mathrm{g}$ of digested peptides were stage tipped according to Rappsilber et al. $^{205}$

Liquid chromatography was developed on a capillary-flow UltiMate 3000 RSLCnano system with a capLC system (Thermo Fisher Scientific, Waltham, MA, USA) coupled to a $15 \mathrm{~cm} \mathrm{C18}$ easy spray column $50 \mu \mathrm{m} \times 150 \mathrm{~mm}, 2 \mu \mathrm{m}$ Acclaim PepMap C18 column at $1.2 \mu \mathrm{L} / \mathrm{min}$ (Thermo Fisher Scientific, Waltham, MA, USA). Using a stepped 3-45\% acetonitrile gradient for $120 \mathrm{~min}$, the samples were sprayed into a Q-Exactive HF-X mass spectrometer (Thermo Fisher Scientific, Waltham, MA, USA) operated in the Top 12 Datadependent acquisition mode. First of a full scan was collected at 60,000 resolution, maximum injection time $50 \mathrm{~ms}$, AGC Target $3.0 \times 10^{6}$, followed by up to $12 \mathrm{MS} 2$ scans at 15,000 resolution with maximum injection time $30 \mathrm{~ms}$, dynamic exclusion set to $25 \mathrm{~s}$, and higher-energy collisional dissociation (HCD) collision energy at $28 \%$. Data were analyzed using MaxQuant software, carbamidomethyl and oxidation of methionine residues were established as fixed and variable modifications, respectively, one missed cleavage was allowed, and false discovery rate (FDR) was fixed at $1 \%$. Data were searched against the $\mathrm{CHO}$ proteome from Uniprot (UP000001075) while including a list of known contaminants. The concentration of $\mathrm{mAb}$ light chain in intracellular compartments containing ER was measured and used as an internal control of cellular protein expression levels. MAb light chain sequence was added to the search database. ${ }^{164}$ Tolerance of $20 \mathrm{ppm}$ was set for the first search mass and MS/MS. The mass spectrometry proteomics data have been deposited to the ProteomeXchange Consortium via the PRIDE $^{206}$ partner repository with the data set identifier PXD021014.

5.12. Processing, Comparison, and Classification of Proteomic Data. A flow diagram that represents data processing, identification of DEPs and gene groups, and their classification into GO categories is depicted in Figure 1. Contaminants and groups identified in reverse database or by PTM were discarded, and protein groups were reduced to one member. All subsequent analyses for each subcellular compartment were carried out in $\mathrm{R}$ language. ${ }^{207}$ The two bestperforming normalization methods from Normalyzer v1.1.1 ${ }^{208}$ were selected for all further analyses. Missing values from each group were imputed by using the quantile regression imputation of left-censored data (QRILC) method. ${ }^{209}$

Protein expression was compared by using $\mathrm{SAM}^{210}$ and ROTS $^{211}$ algorithms. A cut-off of two-fold change and FDR $\leq 0.05$ were used in SAM package, while $B=1000, K=2000$, and FDR $\leq 0.05$ were used for ROTS. DEPs were aligned against Mus musculus proteome (UP000000589) using BLAST + v2.2.24 and mapped and classified by BlastKOALA from KEGG $^{212}$ PANTHER v14.0, ${ }^{213}$ and DAVID v6.8 (EASE < $0.05)^{214}$ 
Defined sets of genes were statistically compared using the javaGSEA desktop application. ${ }^{215}$ M. musculus GSEA GO terms were obtained from prebuilt gene sets of GO2MSIG. ${ }^{216}$ Collapse data set to gene symbols and metric for ranking genes were set to "false" and "diff of classes," respectively. FDR $<0.25$ and $p<0.05$ were selected as the cut-off value for statistically significant gene sets. ${ }^{215}$

5.13. Statistical Analysis. Pearson's correlation test was carried out between each pair of biological replicates by using ggpubr R package, ${ }^{217}$ to evaluate their relationship. The concentration of $\mathrm{mAb}$ light chain in subcellular compartments containing ER and growth and metabolic parameters were compared between both cell lines by using Student's $t$-test in GraphPad Prism Software v5.01 (GraphPad Software, San Diego, CA, USA).

\section{ASSOCIATED CONTENT}

\section{SI Supporting Information}

The Supporting Information is available free of charge at https://pubs.acs.org/doi/10.1021/acsomega.0c06030.

Profiles of $\mathrm{pH}$ and cations in cell supernatants; purification and biological activity of $\mathrm{mAb}$; intracellular concentration of $\mathrm{mAb}$ light chain; correlation analyses between replicates; classification of DEPs by PANTHER, DAVID, and KEGG; differential proteomic analysis of glycolysis, lipid synthesis, pentose phosphate pathway, TCA cycle, synthesis of cholesterol and proline, fatty acid degradation, and one carbon metabolism; sample identity by each experiment and cell line; classification of altered proteins by KEGG; and differentially enriched gene sets by GSEA (PDF)

Unprocessed MaxQuant output; DEPs by ROTS and SAM algorithms; classification of altered proteins by PANTHER and DAVID; comparison of DEPs with previous proteomics studies; and mapping of altered proteins to the CSP (XLSX)

\section{AUTHOR INFORMATION}

\section{Corresponding Author}

Norma A. Valdez-Cruz - Programa de Investigación de Producción de Biomoléculas, Departamento de Biología Molecular y Biotecnología, Instituto de Investigaciones Biomédicas, Universidad Nacional Autónoma de México, 04510 Ciudad de México, México; o orcid.org/0000-00028581-1173; Email: adri@biomedicas.unam.mx

\section{Authors}

Saumel Pérez-Rodriguez - Programa de Investigación de Producción de Biomoléculas, Departamento de Biología Molecular y Biotecnología, Instituto de Investigaciones Biomédicas, Universidad Nacional Autónoma de México, 04510 Ciudad de México, México; o orcid.org/0000-00033852-008X

Tune Wulff - The Novo Nordisk Foundation Center for Biosustainability, Technical University of Denmark, Kgs. Lyngby 2800, Denmark; 이이.orcid.0000-0002-88221048

Bjørn G. Voldborg - The Novo Nordisk Foundation Center for Biosustainability, Technical University of Denmark, Kgs. Lyngby 2800, Denmark; (1) orcid.org/0000-0002-70051642
Claudia Altamirano - Laboratorio de Cultivos Celulares, Escuela de Ingeniería Bioquímica, Pontificia Universidad Católica de Valparaíso, 2085 Valparaíso, Chile; - orcid.org/0000-0002-6389-086X

Mauricio A. Trujillo-Roldán - Programa de Investigación de Producción de Biomoléculas, Departamento de Biología Molecular y Biotecnología, Instituto de Investigaciones Biomédicas, Universidad Nacional Autónoma de México, 04510 Ciudad de México, México; 이잉.org/0000-0002$7497-4452$

Complete contact information is available at:

https://pubs.acs.org/10.1021/acsomega.0c06030

\section{Notes}

The authors declare no competing financial interest.

\section{ACKNOWLEDGMENTS}

Saumel Pérez-Rodriguez is a doctoral student from Programa de Doctorado en Ciencias Biomédicas, Universidad Nacional Autónoma de México (UNAM) and received fellowship number 396822 from "Consejo Nacional de Ciencia y Tecnología” CONACYT. We thank Dr. Octavio T Ramírez for the donation of one of the cell lines used in this work and the critical review of the manuscript. We thank Dr. Paola Toledo-Ibelles and Inolab Especialistas en Servicio S.A. de C.V. for their support in cell culture, to BSc. Sandra GuerreroPeralta for her contribution to cell culture and antibody purification, and to Dr. Marcela Lizano Soberón and Dr. Alejandro Alagón Cano for their advice and critical review of methodology and experimental results. We also want to extend our gratitude to DNASU repository for providing hIL8 coding plasmid and to Sartorius De México and S.A. De C.V. for their technical assistance, as well as to Nova Biomedicals for providing access to BioProfile FLEX2 Automated Cell Culture Analyzer. This work was supported by "Programa de Apoyo a Proyectos de Investigación e Innovación Tecnológica, Universidad Nacional Autónoma de México" (PAPITUNAM IN210419, IT-200719, IN-208415). This work was partially funded by the National Council for Science and Technology (CONACYT, Consejo Nacional de Ciencia y Tecnología, 247473, 220795). The work carried out at Novo Nordisk Foundation Center for Biosustainability was founded by Novo Nordisk foundation (NNF10CC1016517). Funding sources had no role in study design, data collection and analysis, decision to publish, or preparation of the manuscript.

\section{REFERENCES}

(1) Walsh, G. Biopharmaceutical Benchmarks 2018. Nat. Biotechnol. 2018, 36, 1136.

(2) Berting, A.; Farcet, M. R.; Kreil, T. R. Virus Susceptibility of Chinese Hamster Ovary (CHO) Cells and Detection of Viral Contaminations by Adventitious Agent Testing. Biotechnol. Bioeng. 2010, 106, 598-607.

(3) Goh, J. B.; Ng, S. K. Impact of Host Cell Line Choice on Glycan Profile. Crit. Rev. Biotechnol. 2018, 38, 851-867.

(4) Reinhart, D.; Damjanovic, L.; Kaisermayer, C.; Kunert, R. Benchmarking of Commercially Available CHO Cell Culture Media for Antibody Production. Appl. Microbiol. Biotechnol. 2015, 99, 46454657.

(5) Pérez-Rodriguez, S.; Ramírez-Lira, M. d. J.; Trujillo-Roldán, M. A.; Valdez-Cruz, N. A. Nutrient Supplementation Strategy Improves Cell Concentration and Longevity, Monoclonal Antibody Production and Lactate Metabolism of Chinese Hamster Ovary Cells. Bioengineered 2020, 11, 463-471. 
(6) Lakshmanan, M.; Kok, Y. J.; Lee, A. P.; Kyriakopoulos, S.; Lim, H. L.; Teo, G.; Poh, S. L.; Tang, W. Q.; Hong, J.; Tan, A. H. M.; Bi, X.; Ho, Y. S.; Zhang, P.; Ng, S. K.; Lee, D. Y. Multi-omics profiling of $\mathrm{CHO}$ parental hosts reveals cell line-specific variations in bioprocessing traits. Biotechnol. Bioeng. 2019, 116, 2117-2129.

(7) Ho, S. C. L.; Bardor, M.; Feng, H.; Mariati; Tong, Y. W.; Song, Z.; Yap, M. G. S.; Yang, Y. IRES-Mediated Tricistronic Vectors for Enhancing Generation of High Monoclonal Antibody Expressing CHO Cell Lines. J. Biotechnol. 2012, 157, 130-139.

(8) Rupp, O.; MacDonald, M. L.; Li, S.; Dhiman, H.; Polson, S.; Griep, S.; Heffner, K.; Hernandez, I.; Brinkrolf, K.; Jadhav, V.; Samoudi, M.; Hao, H.; Kingham, B.; Goesmann, A.; Betenbaugh, M. J.; Lewis, N. E.; Borth, N.; Lee, K. H. A Reference Genome of the Chinese Hamster Based on a Hybrid Assembly Strategy. Biotechnol. Bioeng. 2018, 115, 2087-2100.

(9) Baycin-Hizal, D.; Tabb, D. L.; Chaerkady, R.; Chen, L.; Lewis, N. E.; Nagarajan, H.; Sarkaria, V.; Kumar, A.; Wolozny, D.; Colao, J.; Jacobson, E.; Tian, Y.; O’Meally, R. N.; Krag, S. S.; Cole, R. N.; Palsson, B. O.; Zhang, H.; Betenbaugh, M. Proteomic Analysis of Chinese Hamster Ovary Cells. J. Proteome Res. 2012, 11, 5265-5276.

(10) Rupp, O.; Becker, J.; Brinkrolf, K.; Timmermann, C.; Borth, N.; Pühler, A.; Noll, T.; Goesmann, A. Construction of a Public CHO Cell Line Transcript Database Using Versatile Bioinformatics Analysis Pipelines. PLoS One 2014, 9, e85568.

(11) Dietmair, S.; Hodson, M. P.; Quek, L.-E.; Timmins, N. E.; Chrysanthopoulos, P.; Jacob, S. S.; Gray, P.; Nielsen, L. K. Metabolite Profiling of CHO Cells with Different Growth Characteristics. Biotechnol. Bioeng. 2012, 109, 1404-1414.

(12) Bedoya-López, A.; Estrada, K.; Sanchez-Flores, A.; Ramírez, O. T.; Altamirano, C.; Segovia, L.; Miranda-Ríos, J.; Trujillo-Roldán, M. A.; Valdez-Cruz, N. A. Effect of Temperature Downshift on the Transcriptomic Responses of Chinese Hamster Ovary Cells Using Recombinant Human Tissue Plasminogen Activator Production Culture. PLoS One 2016, 11, e0151529.

(13) Baik, J. Y.; Lee, G. M. A DIGE approach for the assessment of differential expression of the $\mathrm{CHO}$ proteome under sodium butyrate addition: Effect of Bcl-xLoverexpression. Biotechnol. Bioeng. 2010, $105,358-367$.

(14) Kim, J. Y.; Kim, Y.-G.; Lee, G. M. Differential In-Gel Electrophoresis (DIGE) Analysis of CHO Cells under Hyperosmotic Pressure: Osmoprotective Effect of Glycine Betaine Addition. Biotechnol. Bioeng. 2012, 109, 1395-1403.

(15) Meleady, P.; Henry, M.; Gammell, P.; Doolan, P.; Sinacore, M.; Melville, M.; Francullo, L.; Leonard, M.; Charlebois, T.; Clynes, M. Proteomic Profiling of CHO Cells with Enhanced RhBMP-2 Productivity Following Co-Expression of PACEsol. Proteomics 2008, $8,2611-2624$.

(16) Henry, M.; Gallagher, C.; Kelly, R. M.; Frye, C. C.; Osborne, M. D.; Brady, C. P.; Barron, N.; Clynes, M.; Meleady, P. Clonal Variation in Productivity and Proteolytic Clipping of an Fc-Fusion Protein in CHO Cells: Proteomic Analysis Suggests a Role for Defective Protein Folding and the UPR. J. Biotechnol. 2018, 281, 2130.

(17) Meleady, P.; Doolan, P.; Henry, M.; Barron, N.; Keenan, J.; O’Sullivan, F.; Clarke, C.; Gammell, P.; Melville, M. W.; Leonard, M.; Clynes, M. Sustained Productivity in Recombinant Chinese Hamster Ovary (CHO) Cell Lines: Proteome Analysis of the Molecular Basis for a Process-Related Phenotype. BMC Biotechnol. 2011, 11, 78.

(18) Carlage, T.; Hincapie, M.; Zang, L.; Lyubarskaya, Y.; Madden, H.; Mhatre, R.; Hancock, W. S. Proteomic Profiling of a HighProducing Chinese Hamster Ovary Cell Culture. Anal. Chem. 2009, $81,7357-7362$.

(19) Hausmann, R.; Chudobová, I.; Spiegel, H.; Schillberg, S. Proteomic Analysis of $\mathrm{CHO}$ Cell Lines Producing High and Low Quantities of a Recombinant Antibody before and after Selection with Methotrexate. J. Biotechnol. 2018, 265, 65-69.

(20) Kang, S.; Ren, D.; Xiao, G.; Daris, K.; Buck, L.; Enyenihi, A. A.; Zubarev, R.; Bondarenko, P. V.; Deshpande, R. Cell Line Profiling to
Improve Monoclonal Antibody Production. Biotechnol. Bioeng. 2014, $111,748-760$.

(21) Nissom, P. M.; Sanny, A.; Kok, Y. J.; Hiang, Y. T.; Chuah, S. H.; Shing, T. K.; Lee, Y. Y.; Wong, K. T. K.; Hu, W.-s.; Sim, M. Y. G.; Philp, R. Transcriptome and Proteome Profiling to Understanding the Biology of High Productivity CHO Cells. Mol. Biotechnol. 2006, 34, 125-140.

(22) Orellana, C. A.; Marcellin, E.; Schulz, B. L.; Nouwens, A. S.; Gray, P. P.; Nielsen, L. K. High-Antibody-Producing Chinese Hamster Ovary Cells up-Regulate Intracellular Protein Transport and Glutathione Synthesis. J. Proteome Res. 2015, 14, 609-618.

(23) Ho, R. Proteomic Analysis of Chinese Hamster Ovary Cells Producing Glycosylated Monoclonal Antibodies, University of Waterloo, 2013.

(24) Sommeregger, W.; Mayrhofer, P.; Steinfellner, W.; Reinhart, D.; Henry, M.; Clynes, M.; Meleady, P.; Kunert, R. Proteomic Differences in Recombinant CHO Cells Producing Two Similar Antibody Fragments. Biotechnol. Bioeng. 2016, 113, 1902-1912.

(25) Hasegawa, H.; Wendling, J.; He, F.; Trilisky, E.; Stevenson, R.; Franey, H.; Kinderman, F.; Li, G.; Piedmonte, D. M.; Osslund, T.; Shen, M.; Ketchem, R. R. In Vivo Crystallization of Human IgG in the Endoplasmic Reticulum of Engineered Chinese Hamster Ovary (CHO) Cells. J. Biol. Chem. 2011, 286, 19917-19931.

(26) Bolt, G.; Kristensen, C.; Steenstrup, T. D. More than One Intracellular Processing Bottleneck Delays the Secretion of Coagulation Factor VII. Thromb. Haemostasis 2008, 100, 204-210.

(27) Rahimpour, A.; Vaziri, B.; Moazzami, R.; Nematollahi, L.; Barkhordari, F.; Kokabee, L.; Adeli, A.; Mahboudi, F. Engineering the Cellular Protein Secretory Pathway for Enhancement of Recombinant Tissue Plasminogen Activator Expression in Chinese Hamster Ovary Cells: Effects of CERT and XBP1s Genes. J. Microbiol. Biotechnol. 2013, 23, 1116-1122.

(28) Dreger, M. Proteome Analysis at the Level of Subcellular Structures. Eur. J. Biochem. 2003, 270, 589-599.

(29) Dreger, M. Subcellular Proteomics. Mass Spectrom. Rev. 2003, 22, 27-56.

(30) Paulo, J. A.; Gaun, A.; Kadiyala, V.; Ghoulidi, A.; Banks, P. A.; Conwell, D. L.; Steen, H. Subcellular Fractionation Enhances Proteome Coverage of Pancreatic Duct Cells. Biochim. Biophys. Acta Protein Proteonomics 2013, 1834, 791-797.

(31) Chandramouli, K.; Qian, P.-Y. Proteomics: Challenges, Techniques and Possibilities to Overcome Biological Sample Complexity. Hum. Genom. Proteonomics 2009, 1, 239204.

(32) Michelsen, U.; von Hagen, J. Isolation of Subcellular Organelles and Structures. In Guide to Protein Purification, 2nd ed.; Burgess, R. R., Deutscher, M. P., Eds.; Academic Press, 2009; Vol. 463; pp 305-328 DOI: 10.1016/S0076-6879(09)63019-6.

(33) Lee, Y. H.; Tan, H. T.; Chung, M. C. M. Subcellular Fractionation Methods and Strategies for Proteomics. Proteomics 2010, 10, 3935-3956.

(34) Foster, L. J.; de Hoog, C. L.; Zhang, Y.; Zhang, Y.; Xie, X.; Mootha, V. K.; Mann, M. A Mammalian Organelle Map by Protein Correlation Profiling. Cell 2006, 125, 187-199.

(35) Yates, J. R.; Gilchrist, A.; Howell, K. E.; Bergeron, J. J. M. Proteomics of Organelles and Large Cellular Structures. Nat. Rev. Mol. Cell Biol. 2005, 6, 702-714.

(36) Andreyev, A. Y.; Shen, Z.; Guan, Z.; Ryan, A.; Fahy, E.; Subramaniam, S.; Raetz, C. R. H.; Briggs, S.; Dennis, E. A. Application of Proteomic Marker Ensembles to Subcellular Organelle Identification*. Mol. Cell. Proteomics 2010, 9, 388-402.

(37) Breuza, L.; Halbeisen, R.; Jenö, P.; Otte, S.; Barlowe, C.; Hong, W.; Hauri, H.-P. Proteomics of Endoplasmic Reticulum-Golgi Intermediate Compartment (ERGIC) Membranes from Brefeldin A-Treated HepG2 Cells Identifies ERGIC-32, a New Cycling Protein That Interacts with Human Erv46. J. Biol. Chem. 2004, 279, 4724247253

(38) Gilchrist, A.; Au, C. E.; Hiding, J.; Bell, A. W.; FernandezRodriguez, J.; Lesimple, S.; Nagaya, H.; Roy, L.; Gosline, S. J. C.; Hallett, M.; Paiement, J.; Kearney, R. E.; Nilsson, T.; Bergeron, J. J. 
M. Quantitative Proteomics Analysis of the Secretory Pathway. Cell 2006, 127, 1265-1281.

(39) Qattan, A. T.; Mulvey, C.; Crawford, M.; Natale, D. A.; Godovac-Zimmermann, J. Quantitative Organelle Proteomics of MCF-7 Breast Cancer Cells Reveals Multiple Subcellular Locations for Proteins in Cellular Functional Processes. J. Proteome Res. 2010, 9, 495-508.

(40) Sánchez-Kopper, A.; Becker, M.; Pfizenmaier, J.; Kessler, C.; Karau, A.; Takors, R. Tracking Dipeptides at Work-Uptake and Intracellular Fate in CHO Culture. Amb. Express 2016, 6, 48.

(41) Imamoto, Y.; Tanaka, H.; Takahashi, K.; Konno, Y.; Suzawa, T. Advantages of AlaGln as an additive to cell culture medium: use with anti-CD20 chimeric antibody-producing POTELLIGENT CHO cell lines. Cytotechnology 2013, 65, 135-143.

(42) Lao, M.-S.; Toth, D. Effects of Ammonium and Lactate on Growth and Metabolism of a Recombinant Chinese Hamster Ovary Cell Culture. Biotechnol. Prog. 1997, 13, 688-691.

(43) Kim, S. H.; Lee, G. M. Functional Expression of Human Pyruvate Carboxylase for Reduced Lactic Acid Formation of Chinese Hamster Ovary Cells (DG44). Appl. Microbiol. Biotechnol. 2007, 76, 659-665.

(44) Burleigh, S. C.; van de Laar, T.; Stroop, C. J.; van Grunsven, W. M.; O’Donoghue, N.; Rudd, P. M.; Davey, G. P. Synergizing Metabolic Flux Analysis and Nucleotide Sugar Metabolism to Understand the Control of Glycosylation of Recombinant Protein in CHO Cells. BMC Biotechnol. 2011, 11, 95.

(45) Mosser, M.; Chevalot, I.; Olmos, E.; Blanchard, F.; Kapel, R.; Oriol, E.; Marc, I.; Marc, A. Combination of Yeast Hydrolysates to Improve $\mathrm{CHO}$ Cell Growth and IgG Production. Cytotechnology 2013, 65, 629-641.

(46) Toussaint, C.; Henry, O.; Durocher, Y. Metabolic Engineering of $\mathrm{CHO}$ Cells to Alter Lactate Metabolism during Fed-Batch Cultures. J. Biotechnol. 2016, 217, 122-131.

(47) Buchsteiner, M.; Quek, L. E.; Gray, P.; Nielsen, L. K. Improving Culture Performance and Antibody Production in CHO Cell Culture Processes by Reducing the Warburg Effect. Biotechnol. Bioeng. 2018, 115, 2315-2327.

(48) Mellahi, K.; Brochu, D.; Gilbert, M.; Perrier, M.; Ansorge, S.; Durocher, Y.; Henry, O. Assessment of Fed-Batch Cultivation Strategies for an Inducible CHO Cell Line. J. Biotechnol. 2019, 298, $45-56$.

(49) Torres, M.; Berrios, J.; Rigual, Y.; Latorre, Y.; Vergara, M.; Dickson, A. J.; Altamirano, C. Metabolic Flux Analysis during Galactose and Lactate Co-Consumption Reveals Enhanced Energy Metabolism in Continuous CHO Cell Cultures. Chem. Eng. Sci. 2019, 205, 201-211.

(50) Heffner, K.; Hizal, D. B.; Majewska, N. I.; Kumar, S.; Dhara, V. G.; Zhu, J.; Bowen, M.; Hatton, D.; Yerganian, G.; Yerganian, A.; O’Meally, R.; Cole, R.; Betenbaugh, M. Expanded Chinese Hamster Organ and Cell Line Proteomics Profiling Reveals Tissue-Specific Functionalities. Sci. Rep. 2020, 10, 15841.

(51) Pérez-Rodriguez, S.; de Jesús Ramírez-Lira, M.; Wulff, T.; Voldbor, B. G.; Ramírez, O. T.; Trujillo-Roldán, M. A.; Valdez-Cruz, N. A. Enrichment of Microsomes from Chinese Hamster Ovary Cells by Subcellular Fractionation for Its Use in Proteomic Analysis. PLoS One 2020, 15, e0237930.

(52) Young, J. D. Metabolic Flux Rewiring in Mammalian Cell Cultures. Curr. Opin. Biotechnol. 2013, 24, 1108-1115.

(53) Clarke, C.; Doolan, P.; Barron, N.; Meleady, P.; O’Sullivan, F.; Gammell, P.; Melville, M.; Leonard, M.; Clynes, M. Predicting CellSpecific Productivity from CHO Gene Expression. J. Biotechnol. 2011, 151, 159-165.

(54) Doolan, P.; Melville, M.; Gammell, P.; Sinacore, M.; Meleady, P.; McCarthy, K.; Francullo, L.; Leonard, M.; Charlebois, T.; Clynes, M. Transcriptional Profiling of Gene Expression Changes in a PACETransfected CHO DUKX Cell Line Secreting High Levels of RhBMP2. Mol. Biotechnol. 2008, 39, 187-199.
(55) Edros, R. Z.; McDonnell, S.; Al-Rubeai, M. Using Molecular Markers to Characterize Productivity in Chinese Hamster Ovary Cell Lines. PLoS One 2013, 8, e75935.

(56) Pieper, L. A.; Strotbek, M.; Wenger, T.; Gamer, M.; Olayioye, M. A.; Hausser, A. Secretory Pathway Optimization of CHO Producer Cells by Co-Engineering of the MitosRNA-1978 Target Genes CerS2 and Tbc1D20. Metab. Eng. 2017, 40, 69-79.

(57) Bolt, G.; Steenstrup, T. D.; Kristensen, C. All PostTranslational Modifications except Propeptide Cleavage Are Required for Optimal Secretion of Coagulation Factor VII. Thromb. Haemostasis 2007, 98, 988-997.

(58) Peng, R.-W.; Fussenegger, M. Molecular Engineering of Exocytic Vesicle Traffic Enhances the Productivity of Chinese Hamster Ovary Cells. Biotechnol. Bioeng. 2009, 102, 1170-1181.

(59) Binder, J. X.; Pletscher-Frankild, S.; Tsafou, K.; Stolte, C.; O'Donoghue, S. I.; Schneider, R.; Jensen, L. J. COMPARTMENTS: Unification and Visualization of Protein Subcellular Localization Evidence. Database 2014, 2014, bau012.

(60) Chusainow, J.; Yang, Y. S.; Yeo, J. H. M.; Toh, P. C.; Asvadi, P.; Wong, N. S. C.; Yap, M. G. S. A Study of Monoclonal AntibodyProducing CHO Cell Lines: What Makes a Stable High Producer? Biotechnol. Bioeng. 2009, 102, 1182-1196.

(61) Vergara, M.; Torres, M.; Müller, A.; Avello, V.; Acevedo, C.; Berrios, J.; Reyes, J. G.; Valdez-Cruz, N. A.; Altamirano, C. High Glucose and Low Specific Cell Growth but Not Mild Hypothermia Improve Specific R-Protein Productivity in Chemostat Culture of CHO Cells. PLoS One 2018, 13, e0202098.

(62) Berrios, J.; Díaz-Barrera, A.; Bazán, C.; Altamirano, C. Relationship between Tissue Plasminogen Activator Production and Specific Growth Rate in Chinese Hamster Ovary Cells Cultured in Mannose at Low Temperature. Biotechnol. Lett. 2009, 31, 1493-1497.

(63) Vergara, M.; Becerra, S.; Berrios, J.; Osses, N.; Reyes, J.; Rodríguez-Moyá, M.; Gonzalez, R.; Altamirano, C. Differential Effect of Culture Temperature and Specific Growth Rate on CHO Cell Behavior in Chemostat Culture. PLoS One 2014, 9, e93865.

(64) Nagasawa, M.; Kanzaki, M.; Iino, Y.; Morishita, Y.; Kojima, I. Identification of a Novel Chloride Channel Expressed in the Endoplasmic Reticulum, Golgi Apparatus, and Nucleus. J. Biol. Chem. 2001, 276, 20413-20418.

(65) Jia, Y.; Jucius, T. J.; Cook, S. A.; Ackerman, S. L. Loss of Clcc1 Results in ER Stress, Misfolded Protein Accumulation, and Neurodegeneration. J. Neurosci. 2015, 35, 3001-3009.

(66) Lee, A.-H.; Iwakoshi, N. N.; Glimcher, L. H. XBP-1 Regulates a Subset of Endoplasmic Reticulum Resident Chaperone Genes in the Unfolded Protein Response. Mol. Cell. Biol. 2003, 23, 7448-7459.

(67) Gao, D.; Bambang, I. F.; Putti, T. C.; Lee, Y. K.; Richardson, D. R.; Zhang, D. ERp29 Induces Breast Cancer Cell Growth Arrest and Survival through Modulation of Activation of P38 and Upregulation of ER Stress Protein P58IPK. Lab. Invest. 2012, 92, 200-213.

(68) van Huizen, R.; Martindale, J. L.; Gorospe, M.; Holbrook, N. J. P58IPK, a Novel Endoplasmic Reticulum Stress-inducible Protein and Potential Negative Regulator of eIF $2 \alpha$ Signaling. J. Biol. Chem. 2003, 278, 15558-15564.

(69) Melville, M. W.; Tan, S.-L.; Wambach, M.; Song, J.; Morimoto, R. I.; Katze, M. G. The Cellular Inhibitor of the PKR Protein Kinase, P58IPK, Is an Influenza Virus-activated Co-chaperone That Modulates Heat Shock Protein 70 Activity. J. Biol. Chem. 1999, 274, 3797-3803.

(70) Jonikas, M. C.; Collins, S. R.; Denic, V.; Oh, E.; Quan, E. M.; Schmid, V.; Weibezahn, J.; Schwappach, B.; Walter, P.; Weissman, J. S.; Schuldiner, M. Comprehensive Characterization of Genes Required for Protein Folding in the Endoplasmic Reticulum. Science 2009, 323, 1693-1697.

(71) Richard, M.; Boulin, T.; Robert, V. J. P.; Richmond, J. E.; Bessereau, J.-L. Biosynthesis of Ionotropic Acetylcholine Receptors Requires the Evolutionarily Conserved ER Membrane Complex. Proc. Natl. Acad. Sci. U.S.A. 2013, 110, E1055-E1063.

(72) Satoh, T.; Ohba, A.; Liu, Z.; Inagaki, T.; Satoh, A. K. DPob/ EMC Is Essential for Biosynthesis of Rhodopsin and Other Multi-Pass 
Membrane Proteins in Drosophila Photoreceptors. eLife 2015, 4, e06306.

(73) Christianson, J. C.; Olzmann, J. A.; Shaler, T. A.; Sowa, M. E.; Bennett, E. J.; Richter, C. M.; Tyler, R. E.; Greenblatt, E. J.; Wade Harper, J.; Kopito, R. R. Defining Human ERAD Networks through an Integrative Mapping Strategy. Nat. Cell Biol. 2011, 14, 93-105.

(74) Bernasconi, R.; Pertel, T.; Luban, J.; Molinari, M. A Dual Task for the Xbpl-responsive OS-9 Variants in the Mammalian Endoplasmic Reticulum. J. Biol. Chem. 2008, 283, 16446-16454.

(75) Alcock, F.; Swanton, E. Mammalian OS-9 Is Upregulated in Response to Endoplasmic Reticulum Stress and Facilitates Ubiquitination of Misfolded Glycoproteins. J. Mol. Biol. 2009, 385, 10321042

(76) Christianson, J. C.; Shaler, T. A.; Tyler, R. E.; Kopito, R. R. OS9 and GRP94 deliver mutant $\alpha 1$-antitrypsin to the Hrd1-SEL1L ubiquitin ligase complex for ERAD. Nat. Cell Biol. 2008, 10, 272-282.

(77) van der Goot, A. T.; Pearce, M. M. P.; Leto, D. E.; Shaler, T. A.; Kopito, R. R. Redundant and Antagonistic Roles of XTP3B and OS9 in Decoding Glycan and Non-Glycan Degrons in ER-Associated Degradation. Mol. Cell 2018, 70, 516-530.

(78) Komatsu, M.; Chiba, T.; Tatsumi, K.; Iemura, S.-i.; Tanida, I.; Okazaki, N.; Ueno, T.; Kominami, E.; Natsume, T.; Tanaka, K. A Novel Protein-Conjugating System for Ufm1, a Ubiquitin-Fold Modifier. EMBO J. 2004, 23, 1977-1986.

(79) Homrich, M.; Wobst, H.; Laurini, C.; Sabrowski, J.; Schmitz, B.; Diestel, S. Cytoplasmic Domain of NCAM140 Interacts with Ubiquitin-Fold Modifier-Conjugating Enzyme-1 (Ufc1). Exp. Cell Res. 2014, 324, 192-199.

(80) Yoo, H. M.; Kang, S. H.; Kim, J. Y.; Lee, J. E.; Seong, M. W.; Lee, S. W.; Ka, S. H.; Sou, Y.-S.; Komatsu, M.; Tanaka, K.; Lee, S. T.; Noh, D. Y.; Baek, S. H.; Jeon, Y. J.; Chung, C. H. Modification of ASC1 by UFM1 Is Crucial for ER $\alpha$ Transactivation and Breast Cancer Development. Mol. Cell 2014, 56, 261-274.

(81) Zhang, Y.; Zhang, M.; Wu, J.; Lei, G.; Li, H. Transcriptional Regulation of the Ufm1 Conjugation System in Response to Disturbance of the Endoplasmic Reticulum Homeostasis and Inhibition of Vesicle Trafficking. PLoS One 2012, 7, e48587.

(82) Barry, S. T.; Critchley, D. R. The RhoA-Dependent Assembly of Focal Adhesions in Swiss 3T3 Cells Is Associated with Increased Tyrosine Phosphorylation and the Recruitment of Both Pp125FAK and Protein Kinase C-Delta to Focal Adhesions. J. Cell Sci. 1994, 107, 2033-2045

(83) Greene, M. W.; Burrington, C. M.; Ruhoff, M. S.; Johnson, A. K.; Chongkrairatanakul, T.; Kangwanpornsiri, A. PKC $\delta$ Is Activated in a Dietary Model of Steatohepatitis and Regulates Endoplasmic Reticulum Stress and Cell Death*. J. Biol. Chem. 2010, 285, 4211542129.

(84) Larroque-Cardoso, P.; Swiader, A.; Ingueneau, C.; NègreSalvayre, A.; Elbaz, M.; Reyland, M. E.; Salvayre, R.; Vindis, C. Role of protein kinase $\mathrm{C} \delta$ in ER stress and apoptosis induced by oxidized LDL in human vascular smooth muscle cells. Cell Death Dis. 2013, 4, e520.

(85) Lai, S.; Li, Y.; Kuang, Y.; Cui, H.; Yang, Y.; Sun, W.; Liu, K.; Chen, D.; Yan, Q.; Wen, L. PKC $\delta$ silencing alleviates saturated fatty acid induced ER stress by enhancing SERCA activity. Biosci. Rep. 2017, 37, BSR20170869.

(86) Hwang, S. O.; Boswell, S. A.; Seo, J.-S.; Lee, S. W. Novel Oxidative Stress-Responsive Gene ERS25 Functions as a Regulator of the Heat-Shock and Cell Death Response. J. Biol. Chem. 2008, 283, 13063-13069.

(87) Kilaparty, S. P.; Agarwal, R.; Singh, P.; Kannan, K.; Ali, N. Endoplasmic Reticulum Stress-Induced Apoptosis Accompanies Enhanced Expression of Multiple Inositol Polyphosphate Phosphatase 1 (Minpp1): A Possible Role for Minpp1 in Cellular Stress Response. Cell Stress Chaperones 2016, 21, 593-608.

(88) Lev, S.; Hernandez, J.; Martinez, R.; Chen, A.; Plowman, G.; Schlessinger, J. Identification of a Novel Family of Targets of PYK2 Related to Drosophila Retinal Degeneration B (RdgB) Protein. Mol. Cell. Biol. 1999, 19, 2278-2288.
(89) Fujii, Y.; Shiota, M.; Ohkawa, Y.; Baba, A.; Wanibuchi, H.; Kinashi, T.; Kurosaki, T.; Baba, Y. Surf4 Modulates STIM1Dependent Calcium Entry. Biochem. Biophys. Res. Commun. 2012, 422, 615-620.

(90) Litvak, V.; Dahan, N.; Ramachandran, S.; Sabanay, H.; Lev, S. Maintenance of the Diacylglycerol Level in the Golgi Apparatus by the Nir2 Protein Is Critical for Golgi Secretory Function. Nat. Cell Biol. 2005, 7, 225-234.

(91) Fridmann-Sirkis, Y.; Siniossoglou, S.; Pelham, H. R. TMF Is a Golgin That Binds Rab6 and Influences Golgi Morphology. BMC Cell Biol. 2004, 5, 18.

(92) Miller, V. J.; Sharma, P.; Kudlyk, T. A.; Frost, L.; Rofe, A. P.; Watson, I. J.; Duden, R.; Lowe, M.; Lupashin, V. V.; Ungar, D. Molecular Insights into Vesicle Tethering at the Golgi by the Conserved Oligomeric Golgi (COG) Complex and the Golgin TATA Element Modulatory Factor (TMF). J. Biol. Chem. 2013, 288, 42294240 .

(93) Yamane, J.; Kubo, A.; Nakayama, K.; Yuba-Kubo, A.; Katsuno, T.; Tsukita, S.; Tsukita, S. Functional Involvement of TMF/ARA160 in Rab6-Dependent Retrograde Membrane Traffic. Exp. Cell Res. 2007, 313, 3472-3485.

(94) Ng, M. M.; Dippold, H. C.; Buschman, M. D.; Noakes, C. J.; Field, S. J. GOLPH3L Antagonizes GOLPH3 to Determine Golgi Morphology. Mol. Biol. Cell 2013, 24, 796-808.

(95) Sohda, M.; Misumi, Y.; Yamamoto, A.; Nakamura, N.; Ogata, S.; Sakisaka, S.; Hirose, S.; Ikehara, Y.; Oda, K. Interaction of Golgin84 with the COG Complex Mediates the Intra-Golgi Retrograde Transport. Traffic 2010, 11, 1552-1566.

(96) Diao, A.; Rahman, D.; Pappin, D. J. C.; Lucocq, J.; Lowe, M. The Coiled-Coil Membrane Protein Golgin-84 Is a Novel Rab Effector Required for Golgi Ribbon Formation. J. Cell Biol. 2003, 160, 201-212.

(97) Satoh, A.; Wang, Y.; Malsam, J.; Beard, M. B.; Warren, G. Golgin-84 Is a Rab1 Binding Partner Involved in Golgi Structure. Traffic 2003, 4, 153-161.

(98) Muppirala, M.; Gupta, V.; Swarup, G. Syntaxin 17 Cycles between the ER and ERGIC and Is Required to Maintain the Architecture of ERGIC and Golgi. Biol. Cell. 2011, 103, 333-350.

(99) Laufman, O.; Kedan, A.; Hong, W.; Lev, S. Direct Interaction between the COG Complex and the SM Protein, Sly1, Is Required for Golgi SNARE Pairing. EMBO J. 2009, 28, 2006-2017.

(100) Sato, S.-i.; Inoue, H.; Kogure, T.; Tagaya, M.; Tani, K. GolgiLocalized KIAA0725p Regulates Membrane Trafficking from the Golgi Apparatus to the Plasma Membrane in Mammalian Cells. FEBS Lett. 2010, 584, 4389-4395.

(101) Inoue, H.; Baba, T.; Sato, S.; Ohtsuki, R.; Takemori, A.; Watanabe, T.; Tagaya, M.; Tani, K. Roles of SAM and DDHD Domains in Mammalian Intracellular Phospholipase A1 KIAA0725p. Biochim. Biophys. Acta 2012, 1823, 930-939.

(102) Nakajima, K.-i.; Mizoguchi, T.; Nagahama, M.; Tagaya, M.; Tani, K.; Sonoda, H.; Aoki, J.; Tani, H. A Novel Phospholipase A1 with Sequence Homology to a Mammalian Sec23p-Interacting Protein, P125. J. Biol. Chem. 2002, 277, 11329-11335.

(103) Morikawa, R. K.; Aoki, J.; Kano, F.; Murata, M.; Yamamoto, A.; Tsujimoto, M.; Arai, H. Intracellular Phospholipase Al $\gamma$ (iPLAl $\gamma$ ) Is a Novel Factor Involved in Coat Protein Complex I- and Rab6independent Retrograde Transport between the Endoplasmic Reticulum and the Golgi Complex. J. Biol. Chem. 2009, 284, 26620-26630.

(104) Fleig, L.; Bergbold, N.; Sahasrabudhe, P.; Geiger, B.; Kaltak, L.; Lemberg, M. K. Ubiquitin-Dependent Intramembrane Rhomboid Protease Promotes ERAD of Membrane Proteins. Mol. Cell 2012, 47, $558-569$.

(105) Gaburjakova, M.; Gaburjakova, J.; Reiken, S.; Huang, F.; Marx, S. O.; Rosemblit, N.; Marks, A. R. FKBP12 Binding Modulates Ryanodine Receptor Channel Gating. J. Biol. Chem. 2001, 276, 16931-16935.

(106) Vervliet, T.; Parys, J. B.; Bultynck, G. Bcl-2 and FKBP12 Bind to IP3 and Ryanodine Receptors at Overlapping Sites: The 
Complexity of Protein-Protein Interactions for Channel Regulation. Biochem. Soc. Trans. 2015, 43, 396-404.

(107) Chiu, C.-F.; Ghanekar, Y.; Frost, L.; Diao, A.; Morrison, D.; McKenzie, E.; Lowe, M. ZFPL1, a Novel Ring Finger Protein Required for Cis-Golgi Integrity and Efficient ER-to-Golgi Transport. EMBO J. 2008, 27, 934-947.

(108) Sönnichsen, B.; Lowe, M.; Levine, T.; Jämsä, E.; DiracSvejstrup, B.; Warren, G. A Role for Giantin in Docking COPI Vesicles to Golgi Membranes. J. Cell Biol. 1998, 140, 1013-1021.

(109) Stevenson, N. L.; Bergen, D. J. M.; Skinner, R. E. H.; Kague, E.; Martin-Silverstone, E.; Robson Brown, K. A.; Hammond, C. L.; Stephens, D. J. Giantin-Knockout Models Reveal a Feedback Loop between Golgi Function and Glycosyltransferase Expression. J. Cell Sci. 2017, 130, 4132-4143.

(110) Bhat, G.; Hothpet, V.-R.; Lin, M.-F.; Cheng, P.-W. Shifted Golgi targeting of glycosyltransferases and $\alpha$-mannosidase IA from giantin to GM130-GRASP65 results in formation of high mannose $\mathrm{N}$ -glycans in aggressive prostate cancer cells. Biochim. Biophys. Acta Gen. Subj. 2017, 1861, 2891-2901.

(111) Katayama, K.; Kuriki, M.; Kamiya, T.; Tochigi, Y.; Suzuki, H. Giantin Is Required for Coordinated Production of Aggrecan, Link Protein and Type XI Collagen during Chondrogenesis. Biochem. Biophys. Res. Commun. 2018, 499, 459-465.

(112) Alvarez, C.; Garcia-Mata, R.; Hauri, H.-P.; Sztul, E. The P115Interactive Proteins GM130 and Giantin Participate in Endoplasmic Reticulum-Golgi Traffic. J. Biol. Chem. 2001, 276, 2693-2700.

(113) Malsam, J.; Satoh, A.; Pelletier, L.; Warren, G. Golgin Tethers Define Subpopulations of COPI Vesicles. Science 2005, 307, 10951098

(114) Wan, L.; Molloy, S. S.; Thomas, L.; Liu, G.; Xiang, Y.; Rybak, S. L.; Thomas, G. PACS-1 Defines a Novel Gene Family of Cytosolic Sorting Proteins Required for Trans-Golgi Network Localization. Cell 1998, 94, 205-216.

(115) Crump, C. M.; Xiang, Y.; Thomas, L.; Gu, F.; Austin, C.; Tooze, S. A.; Thomas, G. PACS-1 Binding to Adaptors Is Required for Acidic Cluster Motif-Mediated Protein Traffic. EMBO J. 2001, 20, 2191-2201.

(116) Köttgen, M.; Benzing, T.; Simmen, T.; Tauber, R.; Buchholz, B.; Feliciangeli, S.; Huber, T. B.; Schermer, B.; Kramer-Zucker, A.; Höpker, K.; Simmen, K. C.; Tschucke, C. C.; Sandford, R.; Kim, E.; Thomas, G.; Walz, G. Trafficking of TRPP2 by PACS Proteins Represents a Novel Mechanism of Ion Channel Regulation. EMBO J. 2005, 24, 705-716.

(117) Popoff, V.; Adolf, F.; Brugger, B.; Wieland, F. COPI Budding within the Golgi Stack. Cold Spring Harbor Perspect. Biol. 2011, 3, a005231.

(118) Wang, Y.-N.; Wang, H.; Yamaguchi, H.; Lee, H.-J.; Lee, H.-H.; Hung, M.-C. COPI-Mediated Retrograde Trafficking from the Golgi to the ER Regulates EGFR Nuclear Transport. Biochem. Biophys. Res. Commun. 2010, 399, 498-504.

(119) Duden, R. ER-to-Golgi Transport: COP I and COP II Function (Review). Mol. Membr. Biol. 2003, 20, 197-207.

(120) Futatsumori, M.; Kasai, K.; Takatsu, H.; Shin, H.-W.; Nakayama, K. Identification and Characterization of Novel Isoforms of COP I Subunits. Biochem. J. 2000, 128, 793-801.

(121) Wegmann, D.; Hess, P.; Baier, C.; Wieland, F. T.; Reinhard, C. Novel Isotypic $\gamma / \zeta$ Subunits Reveal Three Coatomer Complexes in Mammals. Mol. Cell. Biol. 2004, 24, 1070-1080.

(122) Popoff, V.; Langer, J. D.; Reckmann, I.; Hellwig, A.; Kahn, R. A.; Brügger, B.; Wieland, F. T. Several ADP-ribosylation Factor (Arf) Isoforms Support COPI Vesicle Formation*. J. Biol. Chem. 2011, 286, 35634-35642.

(123) Kuai, J.; Boman, A. L.; Arnold, R. S.; Zhu, X.; Kahn, R. A. Effects of Activated ADP-Ribosylation Factors on Golgi Morphology Require Neither Activation of Phospholipase D1 nor Recruitment of Coatomer. J. Biol. Chem. 2000, 275, 4022-4032.

(124) Wu, J.-Y.; Kuo, C.-C. ADP-Ribosylation Factor 3 Mediates Cytidine-Phosphate-Guanosine Oligodeoxynucleotide-Induced Re- sponses by Regulating Toll-Like Receptor 9 Trafficking. J. Innate Immun. 2015, 7, 623-636.

(125) Kondo, Y.; Hanai, A.; Nakai, W.; Katoh, Y.; Nakayama, K.; Shin, H.-W. ARF1 and ARF3 Are Required for the Integrity of Recycling Endosomes and the Recycling Pathway. Cell Struct. Funct. 2012, 37, 141-154.

(126) Volpicelli-Daley, L. A.; Li, Y.; Zhang, C.-J.; Kahn, R. A. Isoform-Selective Effects of the Depletion of ADP-Ribosylation Factors 1-5 on Membrane Traffic. Mol. Biol. Cell 2005, 16, 44954508.

(127) Manolea, F.; Chun, J.; Chen, D. W.; Clarke, I.; Summerfeldt, N.; Dacks, J. B.; Melançon, P. Arf3 Is Activated Uniquely at the Trans-Golgi Network by Brefeldin A-Inhibited Guanine Nucleotide Exchange Factors. Mol. Biol. Cell 2010, 21, 1836-1849.

(128) la Cour, J. M.; Schindler, A. J.; Berchtold, M. W.; Schekman, R. ALG-2 Attenuates COPII Budding in Vitro and Stabilizes the Sec23/Sec31A Complex. PLoS One 2013, 8, e75309.

(129) Kanadome, T.; Shibata, H.; Kuwata, K.; Takahara, T.; Maki, M. The calcium-binding protein ALG-2 promotes endoplasmic reticulum exit site localization and polymerization of Trk-fused gene (TFG) protein. FEBS J. 2017, 284, 56-76.

(130) Yamasaki, A.; Tani, K.; Yamamoto, A.; Kitamura, N.; Komada, M. The Ca2+-Binding Protein ALG-2 Is Recruited to Endoplasmic Reticulum Exit Sites by Sec31A and Stabilizes the Localization of Sec31A. Mol. Biol. Cell 2006, 17, 4876-4887.

(131) Takahara, T.; Inoue, K.; Arai, Y.; Kuwata, K.; Shibata, H.; Maki, M. The Calcium-Binding Protein ALG-2 Regulates Protein Secretion and Trafficking via Interactions with MISSL and MAP1B Proteins. J. Biol. Chem. 2017, 292, 17057-17072.

(132) Waschbüsch, D.; Michels, H.; Strassheim, S.; Ossendorf, E.; Kessler, D.; Gloeckner, C. J.; Barnekow, A. LRRK2 Transport Is Regulated by Its Novel Interacting Partner Rab32. PLoS One 2014, 9, e111632.

(133) Waschbüsch, D.; Hübel, N.; Ossendorf, E.; Lobbestael, E.; Baekelandt, V.; Lindsay, A. J.; McCaffrey, M. W.; Khan, A. R.; Barnekow, A. Rab32 Interacts with SNX6 and Affects RetromerDependent Golgi Trafficking. PLoS One 2019, 14, e0208889.

(134) Wan, C.; Fu, J.; Wang, Y.; Miao, S.; Song, W.; Wang, L. Exosome-Related Multi-Pass Transmembrane Protein TSAP6 Is a Target of Rhomboid Protease RHBDD1-Induced Proteolysis. PLoS One 2012, 7, e37452.

(135) Wunderle, L.; Knopf, J. D.; Kühnle, N.; Morlé, A.; Hehn, B.; Adrain, C.; Strisovsky, K.; Freeman, M.; Lemberg, M. K. Rhomboid intramembrane protease RHBDL4 triggers ER-export and noncanonical secretion of membrane-anchored TGF $\alpha$. Sci. Rep. 2016, 6, 27342.

(136) Zong, M.; Satoh, A.; Yu, M. K.; Siu, K. Y.; Ng, W. Y.; Chan, H. C.; Tanner, J. A.; Yu, S. TRAPPC9 Mediates the Interaction between p150Glued and COPII Vesicles at the Target Membrane. PLoS One 2012, 7, e29995.

(137) Gordon, D. E.; Bond, L. M.; Sahlender, D. A.; Peden, A. A. A Targeted SiRNA Screen to Identify SNAREs Required for Constitutive Secretion in Mammalian Cells. Traffic 2010, 11, 1191-1204.

(138) Li, Y.; Gallwitz, D.; Peng, R. Structure-Based Functional Analysis Reveals a Role for the SM Protein Slylp in Retrograde Transport to the Endoplasmic Reticulum. Mol. Biol. Cell 2005, 16, 3951-3962.

(139) Dascher, C.; Balch, W. E. Mammalian Sly1 Regulates Syntaxin 5 Function in Endoplasmic Reticulum to Golgi Transport. J. Biol. Chem. 1996, 271, 15866-15869.

(140) Demircioglu, F. E.; Burkhardt, P.; Fasshauer, D. The SM Protein Sly1 Accelerates Assembly of the ER-Golgi SNARE Complex. Proc. Natl. Acad. Sci. U.S.A. 2014, 111, 13828-13833.

(141) Renna, M.; Schaffner, C.; Winslow, A. R.; Menzies, F. M.; Peden, A. A.; Floto, R. A.; Rubinsztein, D. C. Autophagic Substrate Clearance Requires Activity of the Syntaxin-5 SNARE Complex. J. Cell Sci. 2011, 124, 469-482. 
(142) Hou, J.; Tyo, K.; Liu, Z.; Petranovic, D.; Nielsen, J. Engineering of Vesicle Trafficking Improves Heterologous Protein Secretion in Saccharomyces Cerevisiae. Metab. Eng. 2012, 14, 120127.

(143) Guan, B.; Chen, F.; Su, S.; Duan, Z.; Chen, Y.; Li, H.; Jin, J. Effects of co-overexpression of secretion helper factors on the secretion of a HSA fusion protein (IL2-HSA) inpichia pastoris. Yeast 2016, 33, 587-600.

(144) McCaughey, J.; Miller, V. J.; Stevenson, N. L.; Brown, A. K.; Budnik, A.; Heesom, K. J.; Alibhai, D.; Stephens, D. J. TFG Promotes Organization of Transitional ER and Efficient Collagen Secretion. Cell Rep. 2016, 15, 1648-1659.

(145) Denais, C.; Dent, C. L.; Southgate, L.; Hoyle, J.; Dafou, D.; Trembath, R. C.; Machado, R. D. Dymeclin, the Gene Underlying Dyggve-Melchior-Clausen Syndrome, Encodes a Protein Integral to Extracellular Matrix and Golgi Organization and Is Associated with Protein Secretion Pathways Critical in Bone Development. Hum. Mutat. 2011, 32, 231-239.

(146) Lengfeld, J.; Wang, Q.; Zohlman, A.; Salvarezza, S.; Morgan, S.; Ren, J.; Kato, K.; Rodriguez-Boulan, E.; Liu, B. Protein kinase C $\delta$ regulates the release of collagen type I from vascular smooth muscle cells via regulation of Cdc42. Mol. Biol. Cell 2012, 23, 1955-1963.

(147) Jimenez, S. A.; Gaidarova, S.; Saitta, B.; Sandorfi, N.; Herrich, D. J.; Rosenbloom, J. C.; Kucich, U.; Abrams, W. R.; Rosenbloom, J. Role of protein kinase $C-\delta$ in the regulation of collagen gene expression in scleroderma fibroblasts. J. Clin. Invest. 2001, 108, 13951403.

(148) Ishikawa, Y.; Bächinger, H. P. A Substrate Preference for the Rough Endoplasmic Reticulum Resident Protein FKBP22 during Collagen Biosynthesis. J. Biol. Chem. 2014, 289, 18189-18201.

(149) Ishikawa, Y.; Mizuno, K.; Bächinger, H. P. Ziploc-Ing the Structure 2.0: Endoplasmic Reticulum-Resident Peptidyl Prolyl Isomerases Show Different Activities toward Hydroxyproline. J. Biol. Chem. 2017, 292, 9273-9282.

(150) Hidaka, K.; Kanematsu, T.; Caffrey, J. J.; Takeuchi, H.; Shears, S. B.; Hirata, M. The Importance to Chondrocyte Differentiation of Changes in Expression of the Multiple Inositol Polyphosphate Phosphatase. Exp. Cell Res. 2003, 290, 254-264.

(151) Romano, P. R.; Wang, J.; O’Keefe, R. J.; Puzas, J. E.; Rosier, R. N.; Reynolds, P. R. HiPER1, a Phosphatase of the Endoplasmic Reticulum with a Role in Chondrocyte Maturation. J. Cell Sci. 1998, $111,803-813$.

(152) Caffrey, J. J.; Hidaka, K.; Matsuda, M.; Hirata, M.; Shears, S. B. The Human and Rat Forms of Multiple Inositol Polyphosphate Phosphatase: Functional Homology with a Histidine Acid Phosphatase up-Regulated during Endochondral Ossification. FEBS Lett. 1999, 442, 99-104.

(153) Gai, X.; Tang, B.; Liu, F.; Wu, Y.; Wang, F.; Jing, Y.; Huang, F.; Jin, D.; Wang, L.; Zhang, H. mTOR/miR-145-regulated exosomal GOLM1 promotes hepatocellular carcinoma through augmented GSK-3 $\beta$ /MMPs. J. Genet. Genom. 2019, 46, 235-245.

(154) Aruna; Li, L. M. Overexpression of Golgi Membrane Protein 1 Promotes Non-Small-Cell Carcinoma Aggressiveness by Regulating the Matrix Metallopeptidase 13. Am. J. Cancer Res. 2018, 8, 551-565.

(155) Zhang, R.; Zhu, Z.; Shen, W.; Li, X.; Dhoomun, D. K.; Tian, Y. Golgi Membrane Protein 1 (GOLM1) Promotes Growth and Metastasis of Breast Cancer Cells via Regulating Matrix Metalloproteinase-13 (MMP13). Med. Sci. Monit. 2019, 25, 847-855.

(156) Liu, Y.; Zhang, X.; Zhou, S.; Shi, J.; Xu, Y.; He, J.; Lin, F.; Wei, A.; Zhou, L.; Chen, Z. Knockdown of Golgi phosphoprotein 73 blocks the trafficking of matrix metalloproteinase- 2 in hepatocellular carcinoma cells and inhibits cell invasion. J. Cell. Mol. Med. 2019, 23, 2399-2409.

(157) Rötter, J.; Kuiper, R. P.; Bouw, G.; Martens, G. J. M. CellType-Specific and Selectively Induced Expression of Members of the P24 Family of Putative Cargo Receptors. J. Cell Sci. 2002, 115, 10491058 .

(158) Zheng, C.; Liu, H.-H.; Yuan, S.; Zhou, J.; Zhang, B. Molecular Basis of LMAN1 in Coordinating LMAN1-MCFD2 Cargo Receptor
Formation and ER-to-Golgi Transport of FV/FVIII. Blood 2010, 116, 5698-5706.

(159) Zhang, B.; Kaufman, R. J.; Ginsburg, D. LMAN1 and MCFD2 Form a Cargo Receptor Complex and Interact withCoagulation Factor VIII in the Early SecretoryPathway. J. Biol. Chem. 2005, 280, 25881-25886.

(160) Zhu, M.; Zheng, C.; Wei, W.; Everett, L.; Ginsburg, D.; Zhang, B. Analysis of MCFD2- and LMAN1-Deficient Mice Demonstrates Distinct Functions in Vivo. Blood Adv. 2018, 2, 1014-1021.

(161) Emmer, B. T.; Hesketh, G. G.; Kotnik, E.; Tang, V. T.; Lascuna, P. J.; Xiang, J.; Gingras, A.-C.; Chen, X.-W.; Ginsburg, D. The Cargo Receptor SURF4 Promotes the Efficient Cellular Secretion of PCSK9. eLife 2018, 7, e38839.

(162) Saegusa, K.; Sato, M.; Morooka, N.; Hara, T.; Sato, K. SFT-4/ Surf4 Control ER Export of Soluble Cargo Proteins and Participate in ER Exit Site Organization. J. Cell Biol. 2018, 217, 2073-2085.

(163) Yin, Y.; Garcia, M. R.; Novak, A. J.; Saunders, A. M.; Ank, R. S.; Nam, A. S.; Fisher, L. W. Surf4 (Erv29p) Binds Amino-Terminal Tripeptide Motifs of Soluble Cargo Proteins with Different Affinities, Enabling Prioritization of Their Exit from the Endoplasmic Reticulum. PLoS Biol. 2018, 16, e2005140.

(164) Gonzalez, T. N.; Leong, S. R.; Presta, L. G. Nucleic Acids Encoding Humanized Anti-IL-8 Monoclonal Antibodies. U.S. Patent 6,025,158 A, 2000.

(165) Kol, S.; Ley, D.; Wulff, T.; Decker, M.; Arnsdorf, J.; Schoffelen, S.; Hansen, A. H.; Jensen, T. L.; Gutierrez, J. M.; Chiang, A. W. T.; Masson, H. O.; Palsson, B. O.; Voldborg, B. G.; Pedersen, L. E.; Kildegaard, H. F.; Lee, G. M.; Lewis, N. E. Multiplex Secretome Engineering Enhances Recombinant Protein Production and Purity. Nat. Commun. 2020, 11, 1908.

(166) Xie, Y.-Z.; Ma, W.-L.; Meng, J.-M.; Ren, X.-Q. Knockdown of ZFPL1 results in increased autophagy and autophagy-related cell death in NCI-N87 and BGC-823 human gastric carcinoma cell lines. Mol. Med. Rep. 2017, 15, 2633-2642.

(167) Spearman, M.; Dionne, B.; Butler, M. The Role of Glycosylation in Therapeutic Antibodies. In Antibody Expression and Production; Al-Rubeai, M., Ed.; Springer: Dordrecht, 2011; pp 251292.

(168) Zhang, D.; Pan, J.; Xiang, X.; Liu, Y.; Dong, G.; Livingston, M. J.; Chen, J.-K.; Yin, X.-M.; Dong, Z. Protein Kinase C $\delta$ Suppresses Autophagy to Induce Kidney Cell Apoptosis in Cisplatin Nephrotoxicity. J. Am. Soc. Nephrol. 2017, 28, 1131-1144.

(169) Zhang, D.; Xu, X.; Dong, Z. PRKCD/PKC $\delta$ contributes to nephrotoxicity during cisplatin chemotherapy by suppressing autophagy. Autophagy 2017, 13, 631-632.

(170) Wang, C.; Liu, Z.; Huang, X. Rab32 Is Important for Autophagy and Lipid Storage in Drosophila. PLoS One 2012, 7, e32086.

(171) Hirota, Y.; Tanaka, Y. A Small GTPase, Human Rab32, Is Required for the Formation of Autophagic Vacuoles under Basal Conditions. Cell. Mol. Life Sci. 2009, 66, 2913-2932.

(172) Itakura, E.; Kishi-Itakura, C.; Mizushima, N. The HairpinType Tail-Anchored SNARE Syntaxin 17 Targets to Autophagosomes for Fusion with Endosomes/Lysosomes. Cell 2012, 151, 1256-1269. (173) Saleeb, R. S.; Kavanagh, D. M.; Dun, A. R.; Dalgarno, P. A.; Duncan, R. R. A VPS33A-binding motif on syntaxin 17 controls autophagy completion in mammalian cells. J. Biol. Chem. 2019, 294, $4188-4201$.

(174) Uematsu, M.; Nishimura, T.; Sakamaki, Y.; Yamamoto, H.; Mizushima, N. Accumulation of Undegraded Autophagosomes by Expression of Dominant-Negative STX17 (Syntaxin 17) Mutants. Autophagy 2017, 13, 1452-1464.

(175) Cheng, X.; Ma, X.; Ding, X.; Li, L.; Jiang, X.; Shen, Z.; Chen, S.; Liu, W.; Gong, W.; Sun, Q. Pacer Mediates the Function of Class III PI3K and HOPS Complexes in Autophagosome Maturation by Engaging Stx17. Mol. Cell 2017, 65, 1029-1043.

(176) Jiang, P.; Nishimura, T.; Sakamaki, Y.; Itakura, E.; Hatta, T.; Natsume, T.; Mizushima, N. The HOPS Complex Mediates 
Autophagosome-Lysosome Fusion through Interaction with Syntaxin 17. Mol. Biol. Cell 2014, 25, 1327-1337.

(177) Xian, H.; Yang, Q.; Xiao, L.; Shen, H.-M.; Liou, Y.-C. STX17 Dynamically Regulated by Fis1 Induces Mitophagy via Hierarchical Macroautophagic Mechanism. Nat. Commun. 2019, 10, 2059.

(178) Kim, Y. J.; Baek, E.; Lee, J. S.; Lee, G. M. Autophagy and Its Implication in Chinese Hamster Ovary Cell Culture. Biotechnol. Lett. 2013, 35, 1753-1763.

(179) Jardon, M. A.; Sattha, B.; Braasch, K.; Leung, A. O.; Côté, H. C. F.; Butler, M.; Gorski, S. M.; Piret, J. M. Inhibition of GlutamineDependent Autophagy Increases t-PA Production in CHO Cell FedBatch Processes. Biotechnol. Bioeng. 2012, 109, 1228-1238.

(180) Zhang, X.; Han, L.; Zong, H.; Ding, K.; Yuan, Y.; Bai, J.; Zhou, Y.; Zhang, B.; Zhu, J. Enhanced production of anti-PD1 antibody in $\mathrm{CHO}$ cells through transient co-transfection with anti-apoptotic genes Bcl-x L and Mcl-1. Bioprocess Biosyst. Eng. 2018, 41, 633-640.

(181) Lee, J. S.; Ha, T. K.; Park, J. H.; Lee, G. M. Anti-Cell Death Engineering of CHO Cells: Co-Overexpression of Bcl-2 for Apoptosis Inhibition, Beclin-1 for Autophagy Induction. Biotechnol. Bioeng. 2013, 110, 2195-2207.

(182) Baek, E.; Kim, C. L.; Kim, M. G.; Lee, J. S.; Lee, G. M. Chemical Inhibition of Autophagy: Examining Its Potential to Increase the Specific Productivity of Recombinant CHO Cell Lines. Biotechnol. Bioeng. 2016, 113, 1953-1961.

(183) Nasseri, S. S.; Ghaffari, N.; Braasch, K.; Jardon, M. A.; Butler, M.; Kennard, M.; Gopaluni, B.; Piret, J. M. Increased CHO Cell FedBatch Monoclonal Antibody Production Using the Autophagy Inhibitor 3-MA or Gradually Increasing Osmolality. Biochem. Eng. J. 2014, 91, 37-45.

(184) Hirano, Y.; Hendil, K. B.; Yashiroda, H.; Iemura, S.-i.; Nagane, R.; Hioki, Y.; Natsume, T.; Tanaka, K.; Murata, S. A Heterodimeric Complex That Promotes the Assembly of Mammalian 20S Proteasomes. Nature 2005, 437, 1381-1385.

(185) Hirano, Y.; Hayashi, H.; Iemura, S.-I.; Hendil, K. B.; Niwa, S.I.; Kishimoto, T.; Kasahara, M.; Natsume, T.; Tanaka, K.; Murata, S. Cooperation of Multiple Chaperones Required for the Assembly of Mammalian 20S Proteasomes. Mol. Cell 2006, 24, 977-984.

(186) Wu, W.; Sahara, K.; Hirayama, S.; Zhao, X.; Watanabe, A.; Hamazaki, J.; Yashiroda, H.; Murata, S. PAC1-PAC2 proteasome assembly chaperone retains the core $\alpha 4-\alpha 7$ assembly intermediates in the cytoplasm. Genes Cells 2018, 23, 839-848.

(187) Fricke, B.; Heink, S.; Steffen, J.; Kloetzel, P. M.; Krüger, E. The Proteasome Maturation Protein POMP Facilitates Major Steps of $20 S$ Proteasome Formation at the Endoplasmic Reticulum. EMBO Rep. 2007, 8, 1170-1175.

(188) Dahlqvist, J.; Törmä, H.; Badhai, J.; Dahl, N. SiRNA Silencing of Proteasome Maturation Protein (POMP) Activates the Unfolded Protein Response and Constitutes a Model for KLICK Genodermatosis. PLoS One 2012, 7, e29471.

(189) Chondrogianni, N.; Gonos, E. S. Overexpression of HUMP1/ POMP Proteasome Accessory Protein Enhances ProteasomeMediated Antioxidant Defence. Exp. Gerontol. 2007, 42, 899-903.

(190) Goldberg, A. L.; Zhao, J.; Collins, G. A. Blocking Cancer Growth with Less POMP or Proteasomes. Mol. Cell 2015, 59, 143145.

(191) Gatz, S. A.; Salles, D.; Jacobsen, E.-M.; Dörk, T.; Rausch, T.; Aydin, S.; Surowy, H.; Volcic, M.; Vogel, W.; Debatin, K.-M.; Stütz, A. M.; Schwarz, K.; Pannicke, U.; Hess, T.; Korbel, J. O.; Schulz, A. S.; Schumacher, J.; Wiesmüller, L. MCM3APandPOMPMutations Cause a DNA-Repair and DNA-Damage-Signaling Defect in an Immunodeficient Child. Hum. Mutat. 2016, 37, 257-268.

(192) Becker, M. M. M.; Lapouge, K.; Segnitz, B.; Wild, K.; Sinning, I. Structures of Human SRP72 Complexes Provide Insights into SRP RNA Remodeling and Ribosome Interaction. Nucleic Acids Res. 2017, 45, 470-481.

(193) Wild, K.; Juaire, K. D.; Soni, K.; Shanmuganathan, V.; Hendricks, A.; Segnitz, B.; Beckmann, R.; Sinning, I. Reconstitution of the Human SRP System and Quantitative and Systematic Analysis of Its Ribosome Interactions. Nucleic Acids Res. 2019, 47, 3184-3196.
(194) Siegel, V.; Walter, P. Each of the Activities of Signal Recognition Particle (SRP) Is Contained within a Distinct Domain: Analysis of Biochemical Mutants of SRP. Cell 1988, 52, 39-49.

(195) Brown, J. D.; Hann, B. C.; Medzihradszky, K. F.; Niwa, M.; Burlingame, A. L.; Walter, P. Subunits of the Saccharomyces Cerevisiae Signal Recognition Particle Required for Its Functional Expression. EMBO J. 1994, 13, 4390-4400.

(196) Grosshans, H.; Deinert, K.; Hurt, E.; Simos, G. Biogenesis of the Signal Recognition Particle (SRP) Involves Import of SRP Proteins into the Nucleolus, Assembly with the SRP-RNA, and Xpolp-Mediated Export. J. Cell Biol. 2001, 153, 745-762.

(197) Rapiejko, P. J.; Gilmore, R. Empty Site Forms of the SRP54 and $\operatorname{SR} \alpha$ GTPases Mediate Targeting of Ribosome-Nascent Chain Complexes to the Endoplasmic Reticulum. Cell 1997, 89, 703-713.

(198) Ogg, S. C.; Poritz, M. A.; Walter, P. Signal Recognition Particle Receptor Is Important for Cell Growth and Protein Secretion in Saccharomyces Cerevisiae. Mol. Biol. Cell 1992, 3, 895-911.

(199) Mandon, E. C.; Jiang, Y.; Gilmore, R. Dual Recognition of the Ribosome and the Signal Recognition Particle by the SRP Receptor during Protein Targeting to the Endoplasmic Reticulum. J. Cell Biol. 2003, 162, 575-585.

(200) Jadhav, B.; McKenna, M.; Johnson, N.; High, S.; Sinning, I.; Pool, M. R. Mammalian SRP Receptor Switches the Sec61 Translocase from Sec62 to SRP-Dependent Translocation. Nat. Commun. 2015, 6, 10133.

(201) Le Fourn, V.; Girod, P.-A.; Buceta, M.; Regamey, A.; Mermod, N. CHO Cell Engineering to Prevent Polypeptide Aggregation and Improve Therapeutic Protein Secretion. Metab. Eng. 2014, 21, 91102 .

(202) Seiler, C. Y.; Park, J. G.; Sharma, A.; Hunter, P.; Surapaneni, P.; Sedillo, C.; Field, J.; Algar, R.; Price, A.; Steel, J.; Throop, A.; Fiacco, M.; Labaer, J. DNASU Plasmid and PSI:Biology-Materials Repositories: Resources to Accelerate Biological Research. Nucleic Acids Res. 2014, 42, D1253-D1260.

(203) Crowell, A. M. J.; Wall, M. J.; Doucette, A. A. Maximizing Recovery of Water-Soluble Proteins through Acetone Precipitation. Anal. Chim. Acta 2013, 796, 48-54.

(204) Pérez-Rodriguez, S.; Ramírez, O. T.; Trujillo-Roldán, M. A.; Valdez-Cruz, N. A. Comparison of Protein Precipitation Methods for Sample Preparation Prior to Proteomic Analysis of Chinese Hamster Ovary Cell Homogenates. Electron. J. Biotechnol. 2020, 48, 86-94.

(205) Rappsilber, J.; Mann, M.; Ishihama, Y. Protocol for MicroPurification, Enrichment, Pre-Fractionation and Storage of Peptides for Proteomics Using StageTips. Nat. Protoc. 2007, 2, 1896-1906.

(206) Perez-Riverol, Y.; Csordas, A.; Bai, J.; Bernal-Llinares, M.; Hewapathirana, S.; Kundu, D. J.; Inuganti, A.; Griss, J.; Mayer, G.; Eisenacher, M.; Pérez, E.; Uszkoreit, J.; Pfeuffer, J.; Sachsenberg, T.; Yılmaz, S.; Tiwary, S.; Cox, J.; Audain, E.; Walzer, M.; Jarnuczak, A. F.; Ternent, T.; Brazma, A.; Vizcaíno, J. A. The PRIDE Database and Related Tools and Resources in 2019: Improving Support for Quantification Data. Nucleic Acids Res. 2019, 47, D442-D450.

(207) R Core Team. R: A Language and Environment for Statistical Computing; R Foundation for Statistical Computing: Vienna, Austria, 2020.

(208) Chawade, A.; Alexandersson, E.; Levander, F. Normalyzer: A Tool for Rapid Evaluation of Normalization Methods for Omics Data Sets. J. Proteome Res. 2014, 13, 3114-3120.

(209) Lazar, C. ImputeLCMD: A Collection of Methods for LeftCensored Missing Data Imputation, 2015.

(210) Roxas, B. A.; Li, Q. Significance Analysis of Microarray for Relative Quantitation of LC/MS Data in Proteomics. BMC Bioinf. 2008, 9, 187.

(211) Suomi, T.; Seyednasrollah, F.; Jaakkola, M. K.; Faux, T.; Elo, L. L. ROTS: An R Package for Reproducibility-Optimized Statistical Testing. PLoS Comput. Biol. 2017, 13, e1005562.

(212) Kanehisa, M.; Sato, Y.; Morishima, K. BlastKOALA and GhostKOALA: KEGG Tools for Functional Characterization of Genome and Metagenome Sequences. J. Mol. Biol. 2016, 428, 726731. 
(213) Mi, H.; Muruganujan, A.; Huang, X.; Ebert, D.; Mills, C.; Guo, X.; Thomas, P. D. Protocol Update for Large-Scale Genome and Gene Function Analysis with the PANTHER Classification System (v.14.0). Nat. Protoc. 2019, 14, 703-721.

(214) Huang, D. W.; Sherman, B. T.; Lempicki, R. A. Systematic and Integrative Analysis of Large Gene Lists Using DAVID Bioinformatics Resources. Nat. Protoc. 2009, 4, 44-57.

(215) Subramanian, A.; Tamayo, P.; Mootha, V. K.; Mukherjee, S.; Ebert, B. L.; Gillette, M. A.; Paulovich, A.; Pomeroy, S. L.; Golub, T. R.; Lander, E. S.; Mesirov, J. P. Gene Set Enrichment Analysis: A Knowledge-Based Approach for Interpreting Genome-Wide Expression Profiles. Proc. Natl. Acad. Sci. U.S.A. 2005, 102, 15545-15550.

(216) Powell, J. A. C. GO2MSIG, an Automated GO Based MultiSpecies Gene Set Generator for Gene Set Enrichment Analysis. BMC Bioinf. 2014, 15, 146.

(217) Kassambara, A. Ggpubr: "ggplot2" Based Publication Ready Plots, 2020. 